\title{
航空三角測量のブロック調整計算について
}

\author{
栗原昭八*・朝田弘志*
}

\section{The calculation of the block adjustment of aerial triangulation}

by Shohachi Kurihara, Hiroshi Asada

(Toyo Koku Jigyo Co., Ltd.)

\begin{abstract}
A method of block adjustment developed by Toyo Jigyo Co., Ltd. is reported. The system of block adjustment is treated as a sub-system of whole system what is called ToyoKoku-Operating System. The system gives satisfactory results.
\end{abstract}

\section{1. まえがき}

航空三角測量のブロック調整は大きくわけて次の 2 つの目的のために行なわれるのが通常である。

その一つは, 基準点数は多くまり, 単コ一ス調整で 充分調整計算がでさるが，より精度を上げ，かつ全般 的な精度の均一化を目的とし，コース間の不連続性を 除去したり, 基準点の変換残差等の処理をも含めた特 別な計算であり, 主として高度の開発が進んでいる地 域で行なわれる。

他の一つは, 基準点密度が低く, 単コースの調整が 困難であるような地域を対象として少ない基準点か ら，できるだけ精度のよい航空三角成果を出すための 方法である。いづれにしても実用上の地上座標の算出 や地図作成のために行なうもので，経済的であり，か つ迅速性がなくてはならない。

東洋航空事業K.K.に掠いては後 者の目的のためにプログラムが開発 され，林野関係の航空三角測量や， 既撮影の写真を利用する際に, 2,3 モデルづつ数コースにまたがるよう な基準点配置の悪い場合等の調整計 算に，よりよい精度でかつ能率を上 げるため，しばしば用いられてい る。以下にそのまらましと精度につ いてのシュミレーションを紹介す る。

「写真測量」Vol. 9 No. 41970

\section{2. ブロック調整計算プログラムの位置づけ}

当社に招ける電子計算機システムは, TOSBAC3400 モデル21Aにより体系づけられている。このシス テムの大要は図 1 のよなものである。

以上の機器を用いてソフトウェアーとして「東洋航 空オペレーティングシスティム」と呼ぶプログラム群 老開発し常にこ礼よって計算を自動処理している。 オペレーティングシステムの大要は図 2 に示す如き ものであり，その特徴は器械構成が紙テープベースの ため，紙テープでのオペレートが便利なようになって いる。また航空三角測量の計算が50\%以上をしめるの で，航空三角関係のルーチンに重点を扮き，処理スピ ード，処理量等を増すため，アッセンブラ一言語によ って，書か礼ている。JOB の実行は手操作でスタ一 トアドレスをセットして $1 \mathrm{JOB}$ づつ行なうこともで

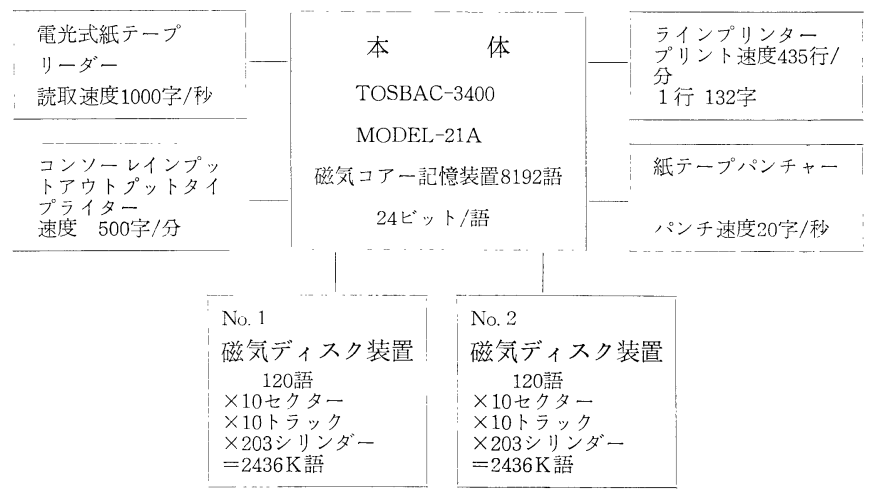

図 1 電子計算機システィム構成図 Computer System of Toyo Koku Jigyo Co. 


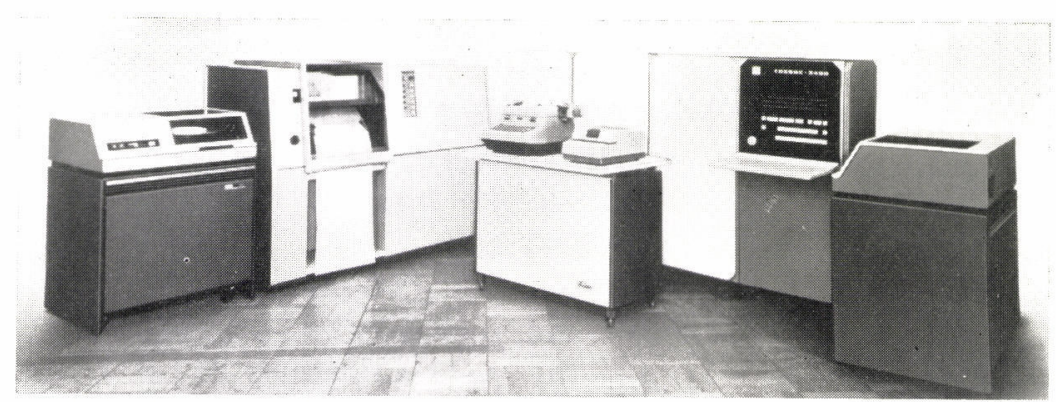

写真 1 TOSBAC-3400 MODEL 21A 電子計算機システィム

きるし，紙テープにコントロールコードをパンチすする ことによって，連続的に処理することもできるように なっている。

さてブロック調整計算はこの航空三角関係のプログ ラム群の中のブロック計算ルーチンを用いて行なうわ けであるが, 他の関連プログラム, 特に対地標定ルー チン，航三整理ルーチン等とは有機的につながりをも ちながら計算が行なわれる。なた航空三角の結果は大 容量の磁気ディスク装置にストアーされ後続計算に用 いられる。このシステムに扰いては，280コース分の 結果を常時保存することができるよう設計されてい る。

\section{3. 単独コース調整計算の概要}

当社のブロック調整計算の方法を説明する前に，単 独コースの調整計算の概要にふれたい。なぜなら変換 のための与件がきまってからの対地標定变換計算は同 じルーチンを用いているからである。

対地標定のブロックダイヤグラムを図 3 に示す。

単独コースの調整計算をするためのデーターは解析 航空三角測量の相互，接続標定結果でもよいし，ぬる いは一級図化機による連続標定の機械座標でもよい。 むろん一級図化機によるものも最初のモデルでの機械 的対地標定は不要である。それらのデーターが記憶装
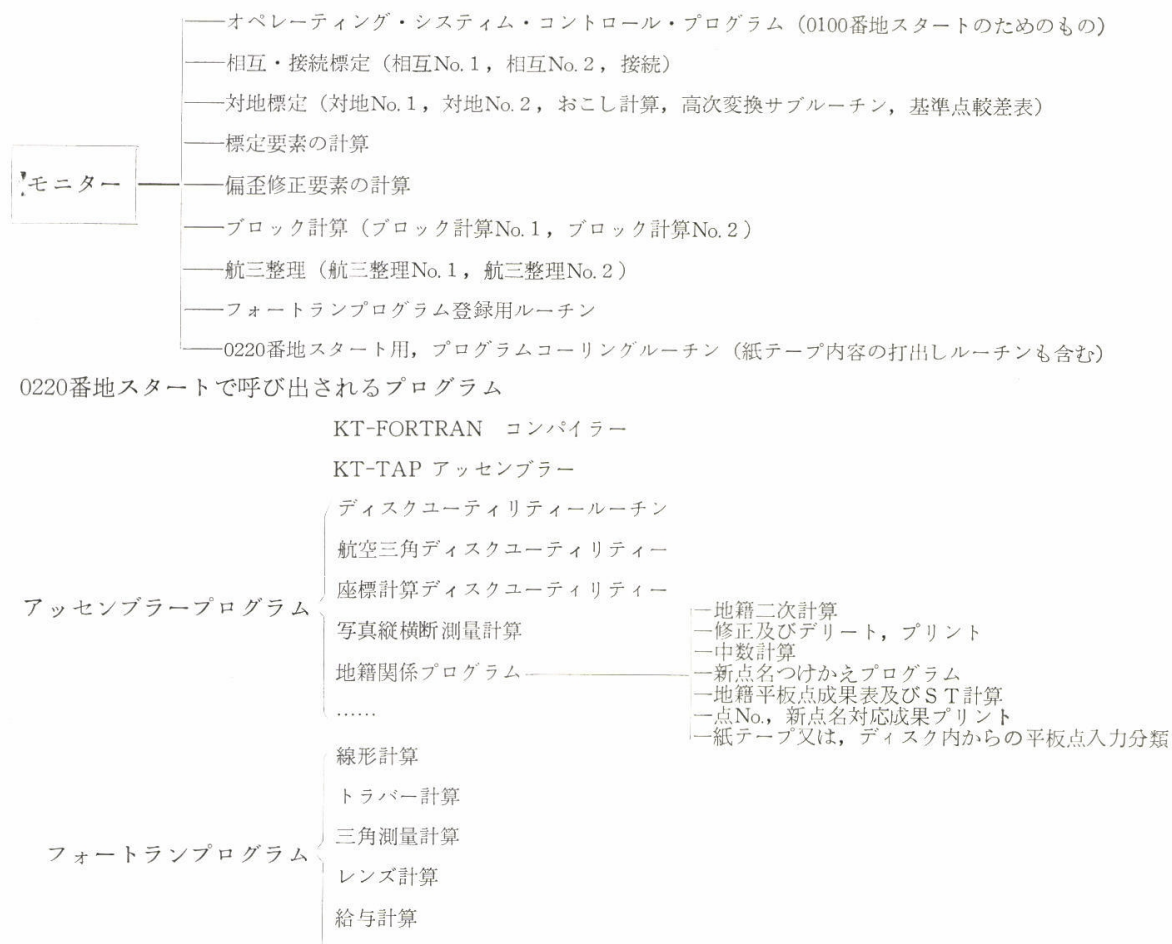

図 2 東洋航空オペレーティングシステム構成図

Computer Operating System of Toyo Koku Jigyo Co. 


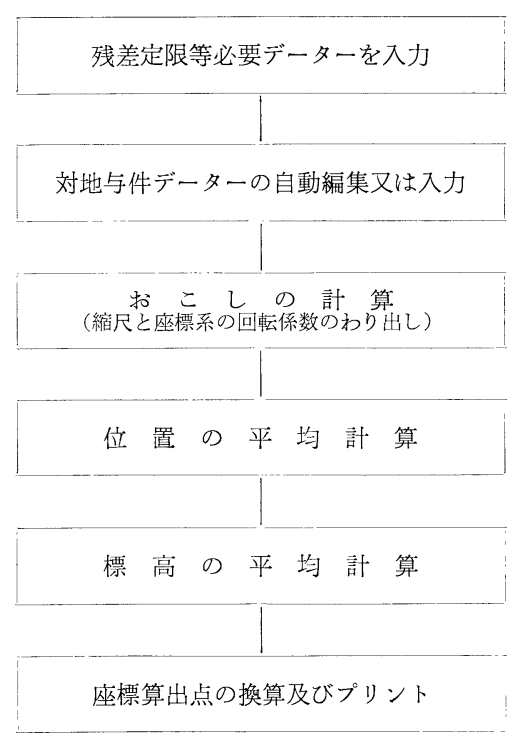

図 3 対地標定の流れ

Flow chart of Absolute Orientation

置にローディングされたなら，先ずそのストリップ座 標の縮尺と概略の標高の対地標定が行なわれる。縮尺 決定には使用しうるすべての位置の基準点を使い，ま た標高を合わせるための基準点は，あらかじ女そとのコ 一スが最もよい形でおこされるような標高基準点を 3 点与光る。その 3 点の選び方は $\Omega$ 方向の傾きを補正す べく，なるべくコースと直角方向にある 2 点と， $\Phi$ 方 向の傾きを修正するために前の 2 点となるべく遠く離 れた他の 1 点を選ぶことが理想である。

この縮尺決定, 標高補正は, ヘルマート変換と 1 次 の 3 次元空間座標変換をくりか元し, 最終的には, 位 置の残差 $10 \mathrm{~m}$ 以内の基準点によって最終縮尺がきめら れる。これまでの過程を「抗こしの計算」と呼んでい る。

いいかえれば括こしの計算は,

$\left(\begin{array}{l}x \\ y \\ z\end{array}\right)=M \cdot\left(\begin{array}{ccl}\cos \Phi & -\sin \Phi \cdot \sin \Phi & \sin \Phi \cdot \cos \Omega \\ 0 & \cos \Omega & \sin \Omega \\ 0 & -\cos \Phi \cdot \sin \Omega & \cos \Phi \cdot \cos \Omega\end{array}\right) \cdot\left(\begin{array}{l}x^{*} \\ y^{*} \\ z^{*}\end{array}\right)$

の $M$ と 3 行 3 列の係数マトリックスを求めることにほ かならない。

おこしの計算が拈わると，次に位置の平均計算を行 なう。変換式はコントロールテープまたはエントリー キーによって与件の数, 配置状況, 接続モデル数等を 考慮して 1 次から 4次までの等角写像変換式を選んで 使うことができる。

\section{[位置の变換式]}

1 次等角写像変換（ヘルマート変換）

$$
\left\{\begin{array}{l}
\bar{X}=a x+b y+X_{0} \\
\bar{Y}=a y-b x+Y_{0}
\end{array}\right.
$$

2 次等角写像変換

$$
\left\{\begin{array}{l}
\bar{X}=a x+b y+c\left(x^{2}-y^{2}\right)+2 d x y+X_{0} \\
\bar{Y}=a y-b y+2 c x y-d\left(x^{2}-y^{2}\right)+Y_{0}
\end{array}\right.
$$

3 次等角写像変換

$$
\left\{\begin{aligned}
\bar{X} & =a x+b y+c\left(x^{2}-y^{2}\right)+2 d x y \\
& +e\left(x^{2}-3 y^{2}\right) x+f\left(3 x^{2}-y^{2}\right) y+X_{0} \\
\bar{Y} & =a y-b x+2 c x y-d\left(x^{2}-y^{2}\right) \\
& +e\left(3 x^{2}-y^{2}\right) y-f\left(x^{2}-3 y^{2}\right) x+Y_{0}
\end{aligned}\right.
$$

4 次等角写像変換

$$
\left\{\begin{aligned}
\bar{X} & =a x+b y+c\left(x^{2}-y^{2}\right)+2 d x y+e\left(x^{2}-3 y^{2}\right) x \\
& +f\left(3 x^{2}-y^{2}\right) y+g\left(x^{4}-6 x^{2} y^{2}+y^{4}\right) \\
& +4 h\left(y^{2}-y^{2}\right) x y+X_{0} \\
\bar{Y} & =a y-b x+2 c x y-d\left(x^{2}-y^{2}\right)+e\left(3 x^{2}-y^{2}\right) y \\
& -f\left(x^{2}-3 y^{2}\right) x+4 g\left(x^{2}-y^{2}\right) x y \\
& -h\left(x^{4}-6 x^{2} y^{2}+y^{4}\right)+Y_{0}
\end{aligned}\right.
$$

ついで標高の平均計算を行なう。これについても位 置と同様で 3 元 1 次変換式から次に示す上5な種々の 変換式を用いることができる。

〔標高の変換式〕

3 元 1 次変換式 $\bar{H}=a x+b y+c+z$

4. 元 2 次変換式 $\bar{H}=a x^{2}+b x+c y+d+z$

(ひ㸚りなし)

5 元 2 次変換式 $\bar{H}=a x^{2}+b x+c x y+d y+e+z$

5 元 3 次変換式 $\bar{H}=a x^{3}+b x^{2}+c x+d y+e+z$

(ひ㸚りし)

6 元 2 次変換式

$$
\bar{H}=a x^{2} y+b x^{2}+c x+d x y+e y+f+z
$$

(2 次のひ效)

位置おょび標高の平均計算は，事前に定限を記憶さ せて沶き，定限外の点が一点でもある場合は，残差の 一番大きいものから一点づつ好いてくりかえし行なわ れ，定限内になるまでくりかえされる。

しかしながら，刺針誤り，偏心計算の誤り，観測違 い, 点名違い, 基準点の成果の誤り，パンチテープの ミス等々，しばしば良いはづの点がはじかれてしまう ことがある。そのような時のために意識的にぬいて見 たい基準点の重量を０に修正することにより不使用と することができるようになっている。

以上の変換係数決定が終るとパスポイント，タイポ イント等の測地座標への変換計算が行なわれ, プリン トアウトされる。

\section{4. ブロック調整計算の基本的理念と方法}

当社で現在行なっているブロック調整計算は，一口 


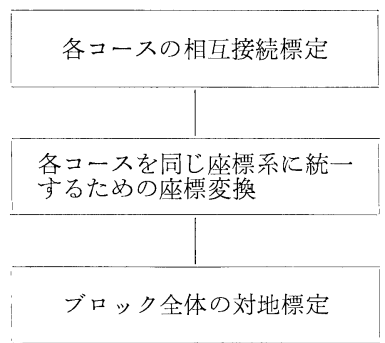

図 4 ブロック計算の流れ

Flow chart of Block Adjust

にいうなら，数コースにまたがる一つのブロック地域 を，まるコースをもとにしてタイポイントやその他の 点を用いてコースとコースを順次つなぎ，同一の座標 系に統一し，それ全体をもら一度適当な交換式を用い て再変換を行なうことである。標準的な工程のフロー チャートは図4の如くである。

この場合注意しなければならないことは，

(i)ブロックの大きさと基準点配置

(ii)最初に行なら骨幹となるべき親コースの選定と 変換式の選定

(iii)親コースに順次接続して行く場合の変換与件と 変換式の選定

(iv)ブロック全体を再変換する時の変換与件と変換 式の選定

（i）については，いくらブロック計算といえども無 制限に大きくしては精度が保てない。コース方向には

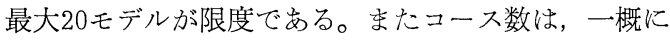
はいえないが水準点が所々にある場合には7,8コ一 ス，ない場合にはせいぜい 5,6 ユースまでである。 もちろん要求される精度で大幅に制約されるのは当然 である。また, 基準点配置は測量の常識であるオープ ン地域をさけるようにブロックを区切るべきである。

(ii)の親コースの選定は, 出来得れば位置の既知点 が 2 点, 標高の既知点が 3 点以上あるようなコースを 選ぶ。またブロック中で一番長いコースを親コースと するのが望ましい。なぜなほコースの接続を行なら 場合，短いコースに長いコースをつなぐような場合に は，オープンとなる部分が多くなるのと，1次以外の 変換式を使う場合，悪い変形を少しでも少なくするた めである。

また，親コースは，位置の基準点が少ない場合には 一次等角写像変換（ヘルマート変換）を行なう。標高 の変換もやはり基準点が少なければ 3 元 1 次変換式で 行なう。もし高次式変換の方が望ましいような基準点 の数と配置であるなら，高次式を用いてょい。

（iii）の各コースの接続は，位置は，接続部分の共通 点, 即ちタイポイントのみで行う。定限内に入るな
ら，なるべく 1 次等角写像変換で行なう。モデル数が 多く 1 次式ではつながらないような場合でも決して 3 次以上の高次式は使用してはならない。2次の等角写 像変換までに止めるべきである。

標高の変換は, 水準测量の成果等があり, 親コース も標高的には充分この段階での計算のみで決定しうる ような配点状況で，接続コースも同様なら，この段階 で標高基準点とタイポイントにより適切な変換式を用 いて行ならのがよい。それに反して標高の基準点が充 分でない場合には, その基準点は無視して, タイポイ ントのみで行なう。変換式は 3 元 1 次が望むしいが, コ一スが長いような場合で定限に入らない場合は，4 元の 2 次式を用いる。この場合，タイポイントの配圆 状態がブロック調整全体の精度を大きく左右するが， それについては後にふれたい。

(iv)のブロック全体の再変換に際して，位置につい ては，ブロック内のすべての位置基準点を用いて行な う。特に( i )でふれた周辺の基準点には注意をはら い,はぶかれないように調整しなければならない。変 換式はブロックの大きさにもよるが，1 次式より順次 あげて行き，変換係数を見て極端な歪がないかどうか 注意しながら適当な変換式を見つける。

標高については，水準路線が密にあり，第一段階の 接続計算の時点でほとんど正しい成果が出たものにつ いては，せいぜい 5 元 2 次式までの低次の変換式を用 いる。

また，標高基準点が少ないブロックにあっては，そ の基準点数や配置にしたがって適当な変換式を適合さ せる。

なお，この段階では，1コースづつの調整のよう に，細長い帯状の調整と異なり，幅広い平面的なブロ ックになることもしばしばあり，X方向にも $Y$ 方向に 82 次, もしくは 3 次的な変形が考光られる。そのた め(6)式〜(10)式の変換式では補正できない場合があ る。そこで，その処理のため，初めXならX方向につ いて平均計算を行ない，次に $x$ と $y$ を入れかえて $Y$ 方 向について再び平均計算を行なえるようになってい る。例えば, 初めに $X$ 万向についての 5 元 2 次の変換 を行ない，次に $Y$ 方向の 4 元 2 次の変換をするなら， 結果的には,

$$
\bar{H}=a x^{2}+b x+b x y+d y+e y^{2}+f+z
$$

なる変換を行なったのとほぼ同じことになる。

\section{5. 高精度を得るための条件}

以上は計算段階での注意事項であるが，計算だけが よくても決して全体的精度は向上しない。例えば，水 準成果もなく，タイポイントのみでコースの接続を行 
なら場合, タイポイントの数が少なかったり, タイポ イントの選点状況がコース方向に直線的であったりし ては, コースとコースのつながりが悪く, 屏風状に不 規則に波うったブロックが形成されてしまう。

このようにブロック調整の精度を高めるためには, 测量計画, 撮影, 現地作業, 観測準備, 観測, 計算の 各段階で, 注意しなければならない問題がある。全般 的に，ブロック計算では位置にくらべて高さの精度が 低下する。これは同じ数の与件があったとすると，位 置の誤差方程式は， $X$ と $Y$ 条件より，標高の誤差方 程式の 2 倍も出て来る。また, タイポイントのみで接 続を行なう時, 一般に位置の接続の安定度と高さの接 続の安定度は, 後者の方が劣る。なぜなら, サイドラ ップが数\%となったとしたら，位置は接続できるが， まづ高さの方は不可能となってしまう。その上, スト リップ座標のねじれは多少の差はあれ，必ずあるのが 普通であるが，30\%位のサイドラップの範囲から，そ のねじれを計算し補正するのは危険であり，不可能で ある。

そこでブロック調整の精度を向上させるための種々 の条件を列記してみる。

\section{測量計画段階}

（a) 撮影範囲, 测量範囲, 現地測量計 画, 要求 精 度, ブロック区分等を考慮して, 綿密な計画を立 てる。

\section{撮影段階}

(b) 出来うれば数コースまたは数拾コースにわたる 平面撮影を結ぶための，骨幹コースを適宜撮影す る。縮尺は, 同程度または, 平面コースより小縮 尺がよい。

(c) 骨幹コースが撮影できない場合には, サイドラ ップを標準以上に多めに取るようにする。

\section{現地作業段階}

(d) ブロック調整の弱点である標高精度を向上させ るため, 水準路線をブロックの両サイドと中央附 近に通す。

(e) 位置基準点もオープン部分ができないよう，四 隅には，必ず配置する。

(f) 少ない基準点で数十モデルのブロック調整を行 なうので, 基準点測量の観測, 計算, 対空標識の 確認，刺針，偏心計算等，絶対，誤りは許されな い。かなりの成果の違いも, ブロック調整の段階 では，父の成果に，ついてしまうので，できれ ば，すぐ近くでもよいので，補助点を設けて，千 エックができるようにするのが望ましい。

\section{観測準備段階}

(g) タイポイントはできるだけ多く選点し，コース 方向に一直線にならないよう，じぐざぐに，なる ベくサイドラップーぱいにばらまくようにとる。

\section{観測段階}

(h) できうれば，1ブロック中の各コースは同じ観 測器械で行なうのが望字しい。なぜなら, 各器械 にはそれ特有のく世があるものも市り，コースの 変形にしても，同じような傾向になった方がよい からである。

(i) 機械法にくらべて, 残存縦視差や, 接続標定の 残差の配分を均等に行なえる解析法により，観測 した方がよい。

\section{計算段階}

（j）使用基準点，使用計算式等について 4. の（i ) 〜 (iv)のような注意をする。

\section{6. ブロック調整計算の精度解析のための 実験例}

実際例として，青森県下北地方の国土基本図作成地 域について, 与件数やその配置状況, 使用変換式を変 えて試みてみた。この地域は，三，四等三角点にほと んど対空標識が設置されており，また国土基本図作成 時に, 当社で単コース毎の高精度な航空三角測量が終 っていた。

この地区内から 1 コース平均 11 モデル，4 コース分 をとり出して，モデル地区にえらび，観测データ一 は、まったく同じものを用いて行なってみた。 モデル地区の諸元は,

撮影年月日 昭和 45 年 5 月 24 日

撮影カメラ $\mathrm{RC}-8 \mathrm{f}=152.02$

撮影基準面 平均 $70 \mathrm{~m}$

撮影高度 平均 $3370 \mathrm{~m}$

撮影縮尺 約 $1: 22,000$

$\begin{array}{cccc}\text { ブロック構成 } & \mathrm{C}-1 & \text { No. } 1 \sim \text { No.12 } & 11 \text { モデル } \\ & \mathrm{C}-2 & \text { No. } 1 \sim \mathrm{No} .12 & 11 \text { モデル } \\ & \mathrm{C}-3 & \text { No. } 1 \sim \mathrm{No} .13 & 12 \text { モデル } \\ & \mathrm{C}-4 & \text { No. } 2 \sim \mathrm{No} .13 & 11 \text { モデル } \\ \text { 合計 } & & 45 \text { モデル }\end{array}$

図化可能面積 約 280 方籸

基準点数 1 等三角点 1 点 2 等三角点 1 点 3 等三角点 25 点 4. 等三角点 11 点 合計 38点

観測方法 オートグラフ A-7 による特殊解析 法 (東洋航空事業 K.K. において開発し た独特の解析法である) 


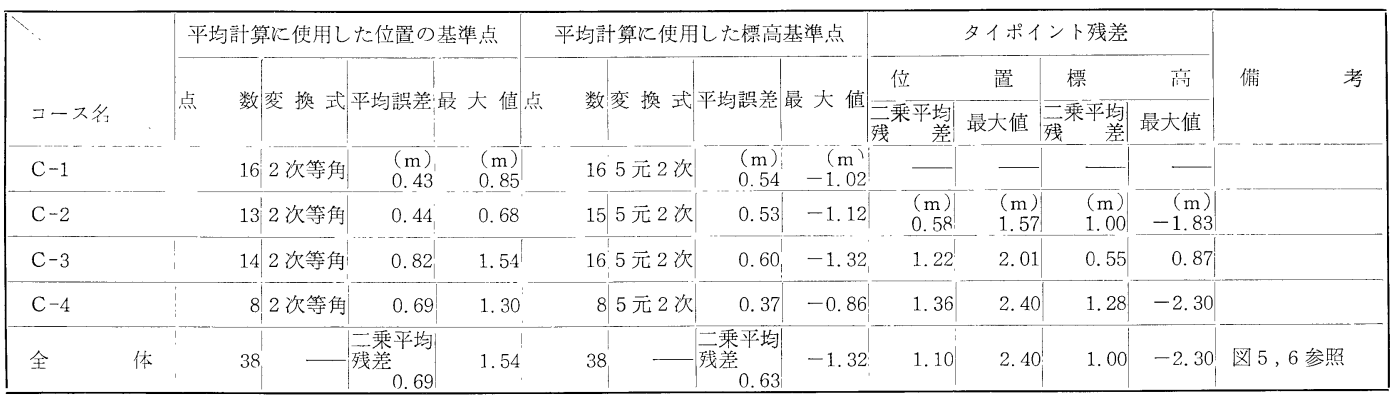

表 1 1コース毎に全与件を用いて調整した時の結果（標準結果）

Results of Strip Adjustment with full control points (Standard Case)

\begin{tabular}{|c|c|c|c|c|c|c|c|c|c|c|c|c|c|c|}
\hline \multirow{4}{*}{\begin{tabular}{|} 
与件 \\
条件 \\
\\
位置, 標高共 \\
4 \\
4
\end{tabular}} & \multirow{3}{*}{$\begin{array}{l}\text { 実験 } \\
\text { No. } \\
\text { A-1 }\end{array}$} & \multicolumn{4}{|c|}{ 平均計算に使用した位置の基準点 } & \multicolumn{4}{|c|}{ 平均計算に使用した標高基準点 } & \multicolumn{4}{|c|}{ 全チェッポイントの残差 } & \multirow[b]{2}{*}{ 備 考 } \\
\hline & & & \multirow{2}{*}{$\begin{array}{l}\text { 変 換 式 } \\
1 \text { 次等角 }\end{array}$} & \multicolumn{2}{|c|}{ 平坛誤差最 大 值| } & \multirow{2}{*}{ 点 数 } & \multirow{2}{*}{ 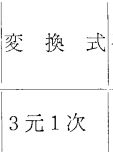 } & \multirow{2}{*}{\begin{tabular}{|r|} 
平均誤差 \\
5.19
\end{tabular}} & \multirow{2}{*}{ 最大值 } & \multirow{2}{*}{ 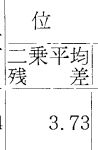 } & \multirow{2}{*}{ 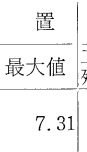 } & \multicolumn{2}{|c|}{$\begin{array}{c}\text { 標 } \\
\text { 三乘平均最大值 } \\
\text { 残 }\end{array}$} & \\
\hline & & 4 & & 4.23 & 5.44 & & & & & & & 6.91 & 10.32 & 図10参照 \\
\hline & $A-2$ & 4 & 2 次等角 & 1.37 & 1.42 & - & - & - & -1 & 1.11 & 1.96 & - & - & 図11 " \\
\hline \multirow{3}{*}{\begin{tabular}{|c} 
位置, 標高共 \\
5 \\
5 点
\end{tabular}} & $A-3$ & 5 & 2 次等角 & 1. 20 & 1.51 & 5 & $\mid \begin{array}{l}x \text { 方向 } \\
5 \text { 元 } 2 \text { 次 }\end{array}$ & 0.00 & 0.00 & 1.09 & 1.79 & 2.77 & 8.69 & 図12 " \\
\hline & $A-4$ & 5 & 3 次等角 & 0.31 & 0.71 & & - & - & & 1.07 & 2.48 & - & - & 図なし \\
\hline & $A-5$ & 5 & 4 次等牦 & 0.00 & 0.00 & & - & - & - & 1.25 & 2.56 & - & - & 図なし \\
\hline \multirow{3}{*}{\begin{tabular}{|c} 
位置, 標高共 \\
7 点
\end{tabular}} & $A-6$ & 7 & 2 次等角 & 1.01 & 1.80 & 7 & $\begin{array}{l}X, Y \text { 方向 } \\
5 \text { 元 } 2 \text { 次 }\end{array}$ & 0.58 & -1.31 & 1.01 & 1.86 & 1.87 & 7.05 & 図13参照 \\
\hline & A-7 & 7 & 3 次等角 & 0.65 & 1.15 & 7 & $\left|\begin{array}{lll}X & 6 \text { 元 } 2 \\
Y & 4 \text { 元 } 2 \text { 次 }\end{array}\right|$ & 0.25 & 0.78 & 0.92 & 2.20 & 1.96 & 6.57 & 図なし \\
\hline & $A-8$ & 7 & 4 次等角 & 0.61 & 1.14 & 7 & $\mid \begin{array}{lll}X & 6 & \text { 元 } \\
Y & 5 & \text { 次 } \\
& 2 & \text { 次 }\end{array}$ & 0.23 & 0.79 & 0.94 & 2. 40 & 1.94 & 6.52 & 図なし \\
\hline \multirow{3}{*}{$\mid \begin{array}{c}\text { 位置, 標高共 } \\
9 \\
9\end{array}$} & $A-9$ & 9 & 2 次等角 & 0.97 & 2.16 & 9 & $\left|\begin{array}{l}X, Y \text { 向 } \\
5 \text { 元 } 2 \text { 次 }\end{array}\right|$ & 0.50 & -0.84 & 0.96 & 2.16 & 1.50 & 4.98 & 図14参照 \\
\hline & $A-10$ & 9 & 3 次等角 & 0.70 & 1.12 & 9 & 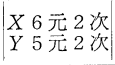 & 0.42 & 1.07 & 0.92 & 2.42 & 1.68 & 4.56 & 図なし \\
\hline & $A-11$ & 9 & 4 次等角 & 0.70 & 1.13 & 9 & $\mid$\begin{tabular}{|}
$X, Y$ 方向 \\
6 元 2 次
\end{tabular} & 0.36 & 1.10 & 0.92 & 2.48 & 1.62 & 4. 34 & 図なし \\
\hline \multirow[t]{2}{*}{ 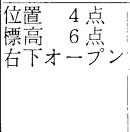 } & A-12 & 4 & 1 次等角 & 3.42 & 5.09 & 6 & \begin{tabular}{|l}
$X$ 方向 \\
4 元 2 次
\end{tabular} & 2.12 & -4.56 & 3.19 & 6.56 & 6.16 & 19.62 & 図15参照 \\
\hline & $A-13$ & 4 & 12 次等角 & 0.57 & 0.97 & 6 & $\mid \begin{array}{l}X, Y \text { 方向 } \\
4 \text { 元 } 2 \text { 次 }\end{array}$ & 0.92 & -2.18 & 1.89 & 5.19 & 7.33 & 25.84 & 図16" \\
\hline \multirow[t]{3}{*}{ 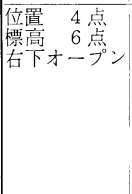 } & A-14 & 6 & ; 1 次等角 & $2.65^{\circ}$ & 5.00 & 8 & $\begin{array}{l}X \text { 方向 } \\
4 \text { 元 } 2 \text { 次 }\end{array}$ & 1.75 & -4.86 & 3. 12 & 6.20 & 5.66 & 18.27 & 図17 " \\
\hline & A-15 & 6 & ２次等角 & 0.67 & 1.03 & 8 & $\left|\begin{array}{l}X, Y \text { 方向 } \\
4 \text { 元 } 2 \text { 次 }\end{array}\right|$ & 1.23 & -2.50 & 1.85 & 5.20 & 6.16 & 2210 & 図18＂ \\
\hline & A-16 & - & 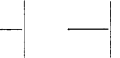 & $\ldots$ & - & 8 & $\mid \begin{array}{lll}X & 5 \text { 元 } 2 \text { 次 } \\
Y & 4 \text { 元 } 2 \text { 次 }\end{array}$ & 0.69 & +1.74 & - & - & 2.69 & -8.22 & 図19 " \\
\hline \multirow{3}{*}{$\begin{array}{l}\text { 位置 } \\
\text { 慓点 } \\
\text { 点点 } \\
\text { 半分オープ }\end{array}$} & A -17 & 6 & ; 1 次等角 & 1.58 & 3.07 & 8 & $\begin{array}{l}X \text { 方向 } \\
4 \text { 元 } 2 \text { 次 }\end{array}$ & 1.69 & -5.01 & 4.53 & 11.29 & 4.22 & 12.88 & 図20" \\
\hline & A-18 & 6 & ２２次等角 & 0.65 & 1.00 & 8 & $\left|\begin{array}{l|}X, Y \text { 万间 } \\
4 \text { 元 } 2 \text { 次 }\end{array}\right|$ & 1.36 & +3.33 & 1.29 & 3.32 & 4.42 & 15.70 & 沟21" \\
\hline & A-19 & 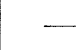 & - & $\ldots$ & 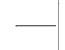 & 8 & $\begin{array}{lll}X & 5 & \text { 元 } 2 \text { 次 } \\
Y & 4 & \text { 元 } 2 \text { 次 }\end{array}$ & 0.71 & -1.81 & 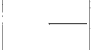 & 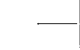 & 8.27 & 21.25 & 図22" \\
\hline
\end{tabular}

表 3 〔Aグループ〕 タイポイントのみの接続によるブロックの与件数, 配点及び使用変換式による変化

Results of Block Adjustment of A-group under several conditions 


\begin{tabular}{|c|c|c|c|c|c|c|c|c|c|c|c|c|c|}
\hline \multirow[b]{3}{*}{ コース名 } & \multicolumn{4}{|c|}{ 平均計算に使用した位置の基準点 } & \multicolumn{4}{|c|}{ 平均計算に使用した標高基準点 } & \multicolumn{4}{|c|}{ タイポイント残差 } & \multirow{3}{*}{ 僃 } \\
\hline & 点. & \multirow{2}{*}{ 变 換 式 } & \multirow{2}{*}{ 平均愦差 } & \multirow{2}{*}{ 最大值 } & \multirow{2}{*}{ 数 } & \multirow{2}{*}{ 変 换 式平 } & \multirow{2}{*}{ 均誤差 } & \multirow{2}{*}{ 最大值 } & \multirow{2}{*}{$\frac{\text { 位 }}{\text { 二乗平均 }}$} & 置 & \multicolumn{2}{|c|}{ 標 䯩 } & \\
\hline & $5 x x$ & & & & & & & & & 最大値 残 & $\begin{array}{l}\text { 乗平均 } \\
\text { 差 }\end{array}$ & 最大值 & \\
\hline $\mathrm{C}-1$ & 2 & 1 次等角 & 0.00 & 0.00 & 3 & 3 元 1 次 & 0.00 & $0.00^{\prime}$ & - & + & -1 & $\square$ & 親コース \\
\hline $\mathrm{C}-2$ & 10 & $\mid 2$ 次等角 $\mid$ & 0.23 & 0.49 & 10 & 4 元 2 次 & 0.78 & $1.69 !$ & 0.56 & 1.74 & 0.89 & -1.69 & \\
\hline $\mathrm{C}-3$ & 11 & 2 次等角 & 0.98 & 2.16 & 11 & 4 完 2 次 & 0.45 & 1.20 & 1.11 & 2.16 & 0.60 & -1.20 & \\
\hline $\mathrm{C}-4$ & 12 & 2 次等角 & 1. 21 & 2.12 & 12 & 4 元 2 次 & 0.60 & -1.17 & $1.29^{\prime}$ & 2.12 & 0.69 & 1.17 & \\
\hline 体 & 35 & - & 0.79 & 2.16 & 35 & - & 0.57 & $1.69^{\prime}$ & 1.03 & 2.16 & 0.74 & -1.69 & 図 7,8,9参照 \\
\hline
\end{tabular}

表 2 タイポイントのみで接続していった場合のブロック組成結果（A グループのブロック組成）

Results at tie points after block construction using only tie points (A-group)

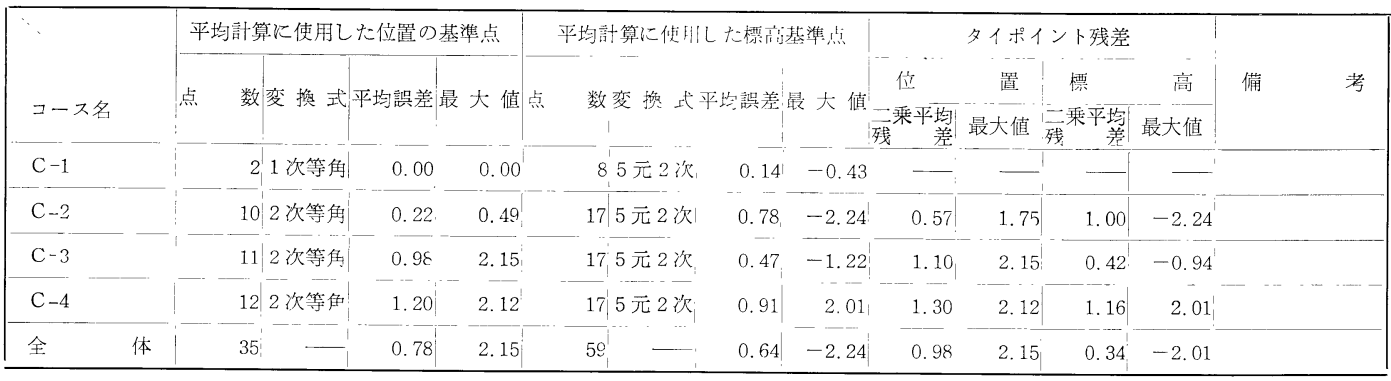

表 4 ブロックの両サイドと中央附近に水準路線を通したと仮定し, タイポイントと標高点を用いてのブロック組成結果 (B-2 ブロック組成時)

Residuals at tie points after block construction using tie points and height control points (B-group)

\begin{tabular}{|c|c|c|c|c|c|c|c|c|c|c|c|c|c|}
\hline \multirow[b]{2}{*}{$\begin{array}{l}\text { 与件 } \\
\text { 条件 }\end{array}$} & \multirow{2}{*}{$\begin{array}{l}\text { 実験 } \\
\text { No. }\end{array}$} & \multicolumn{4}{|c|}{ 平均計算に使用した位置の基準点 } & \multicolumn{3}{|c|}{ 平均計算に使用した標高基準点 } & \multicolumn{4}{|c|}{ 全チェックポイントの残差 } & \multirow[b]{2}{*}{ 備 考 } \\
\hline & & 点 数 & 変 換 式 & 誤差最 & 大値。 & 数|変 換 式 & W & 大值 & 位 & 置 & $\mid \begin{array}{c}\text { 標 } \\
\text { 三乗平埝| } \\
\text { 残若 }\end{array}$ & 最大值 & \\
\hline 両サイド水準路線 & $\mathrm{B}-1$ & & 2 次等角 & 1.14 & 1.68 & $13 \begin{array}{l}X \text { 方向 } \\
5 \text { 元 } 2 \text { 次 }\end{array}$ & 0.51 & 1.44 & $1.14^{\overparen{T}}$ & $\left.2.24\right|^{-}$ & 1.49 & 4.32 & 図23参照 \\
\hline 中央並びに雨サ・1 & B -2 & 5 & $\mid 2$ 次等角 $\mid$ & 1. 23 & 1.88 & $18 \begin{array}{l}X \text { 方向 } \\
5 \text { 元 } 2 \text { 次 }\end{array}$ & 0.52 & 1.37 & 1.20 & 2.43 & 1.00 & 3.20 & 図24 $\prime \prime$ \\
\hline ドに水準路線があ & $\mathrm{B}-3$ & & 3 次等角 & 0.34 & .78 & $\begin{array}{ll} & X 6 \text { 元 } 2 \text { 次 } \\
Y & 5 \text { 元 } 2 \text { 次 }\end{array}$ & 0.49 & 1.40 & 1.17 & 2.47 & 0.90 & 2.83 & 図なし \\
\hline ると仮定した場合 & B -4 & & 4 次等角 & 0.00 & 0.00 & $\begin{array}{l}X, Y \text { 万向 } \\
6 \text { 元 } 2 \text { 次 }\end{array}$ & 0.39 & 1.12 & 1.34 & 2.48 & 0.85 & 2.53 & 図25参照 \\
\hline $\begin{array}{l}\text { 地域全体に水準 } \\
\text { (全与件の高さを } \\
\text { 使用) }\end{array}$ & $B-5$ & & 2 次等角 & 1.43 & 2.20 & $\begin{array}{l}{ }_{38} X \text { 方向 } \\
5 \text { 元 } 2 \text { 次 }\end{array}$ & 0.60 & -1.85 & 1.15 & 2.20 & 0.68 & 1.85 & 四26 " \\
\hline
\end{tabular}

表 5 〔B グループ】 基準点 5 点の他に所々水準測量を行なったと仮定した場合のブロック調整結果

Results of Block Adjustment of B-group under several conditions

パスポイント数 5 点法 ( 1 モデル合計 10 点とな る)

タイポイント数 1 モデルに片側平均 1 点

以上のような条件のもとに，その中の一部の基準点 を位置または標高の与件として使い，他はチェックポ イントとして，その残差を計算して見た。

実験は大別して 2 つ分かれ，〔Aグループ〕とし て，タイポイントのみで各コースを接続するものと，

〔Bグループ〕として標高点がある程度あるものと仮定 して, 各コースの接続に, タイポイントと標高点を用 いたものに分けた。

更に[Aグループ]では最悪の状態を想定してオープ ンの場合をシュミレーシトしてみた。表 3 , 表 5 は各
々の実験例に対する変換残差の平均と最大值打よび, チェックポイントの残差の二乗平均と最大值をまとめ たものである。な挌々の残差分布については, 図 5 〜困26を参照願いたい。

\section{7. 実験結果の考察}

各コース毎に全与件を用いて行なった標準結果を見 ると, 38 与件の平均䛊差は, 位置 $0.69 \mathrm{~m}$, 標高 $0.63 \mathrm{~m}$ で, 最大值が各々 $1.54 \mathrm{~m}$ と $1.32 \mathrm{~m}$ であり, 平均誤差は 各々, $\mathrm{H} / 4,800, \mathrm{H} / 5,200$ 。最大值でも $\mathrm{H} / 2,100, \mathrm{H} /$ 2, 500 である。

A グループの実験結果では, 位置は四隅と中央の 5 点を用い, 2 次等角写像変換でほぼ満足すべき結果と 


\begin{tabular}{|c|c|c|c|c|c|c|c|c|c|c|c|c|c|c|c|c|c|c|}
\hline \multirow{4}{*}{$\begin{array}{l}\text { 与华 } \\
\text { 条件 } \\
\text { 位置・標高共 } 5 \\
\text { 点の場合 }\end{array}$} & \multirow{3}{*}{$\begin{array}{l}\text { 実験 } \\
\text { No. }\end{array}$} & \multicolumn{4}{|c|}{$C-1$} & \multicolumn{4}{|c|}{$C-2$} & \multicolumn{4}{|c|}{$\mathrm{C}-3$} & \multicolumn{4}{|c|}{ C-4 } & \multirow{3}{*}{ 歳考 } \\
\hline & & 位 & 置 & 標 & 高 & 位 & 値 & 標 & 高 & 位 & 值 & 標 & 高 & 位 & 置 & 標 & 高 & \\
\hline & & 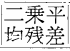 & 最大値 & 均乗平 & 最大値 & 至乗平 & 最大値 & 均㟟平 & 最大値 & 二乗均平 & 最大値 & $\begin{array}{l}\text { 均乗平 } \\
\text { 残差 }\end{array}$ & 最大値 & 均乘平 & 最大値 & 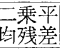 & 最大值 & \\
\hline & $A-3$ & 0.92 & 1.62 & 1.71 & -3.64 & 0.80 & 1.71 & 1.99 & 7.01 & 0.86 & 1.60 & 3. 42 & 8.48 & 0.89 & 1.81 & 3.31 & 6.95 & \\
\hline $\begin{array}{l}\text { 基準点 } 5 \text { 点之両 } \\
\text { 雚の場 } \\
\text { 合 }\end{array}$ & B-1 & 0.87 & 1.54 & 0.83 & $3-1.32$ & 0.80 & 1.48 & 0.53 & 1. 30 & 0.93 & 1.64 & 1.11 & 3.78 & 0.73 & 1.54 & 2.09 & -3.52 & \\
\hline 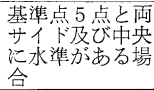 & B-2 & 0.96 & 1.66 & 0.28 & -0.70 & 0.79 & 1.51 & 0.16 & 0.46 & 1.03 & 1.90 & 0.90 & 2.53 & 0.81 & 1.68 & 0.79 & 1. 47 & \\
\hline
\end{tabular}

表 6 パスポイント, タイポイントの標準結果とブロック調整結果との較差

Residuals at tie points and pass points between the results of strip Adjustment and Block Adjustment

なったが，少々よくきすぎた感がある。標高について は，Bグループと比較すると劣っているが，9点あれ ば，充分とはいかないまでも，なんとかつかえると思 う。オープンの例では, いづれにしても, 基準点群か ら, 離れる程悪くなり, 実用にならないことがわか る。

B グループは，位置はA-3 と同じ 5 点にしぼり， 水準が所々にあるすのと想定した。当然のことなが ら, 標高与点が多い程精度が上っていることがわか る。おもしろいことには，標高与件を多くして行く と, 平面の変換残差が少しではあるが大きくなって行 く。しかし全体の精度, 即ち, チェック点の残 差の二乗平均は良くなっている。

以上より実用に供するであろうと思われるも のは, [A-9]〜[A-11]（但し位置は 5 点でも 可), [B-2]〜[B-5]であり，精度と経済性 を考えるなら，[B-2]，[B-3]が最良のもの と思う。

ちなみに，ブロック計算で得られたパスポイ ント, タイポイントの結果と, 標準結果との較 差を各コース每に計算して見た。その二乗平均 と最大值を表 6 に示す。

この実験では，高次式の使用はチエックポイ ントの残差を大幅によくするのには役にたって いない。組成したブロックがすなおな 2 次的傾 向であったことをものがたっている。

\section{8. おわりに}

今回の実験例は平面撮影地域のモデルケース であるが，もちろん線状の場合，環状の場合， またはクロスしているようなコースについても 適用できる。以上のような実験例から見ても， オープンになるようなことは，極力さけなけれ ばならない。また平面位置に対して，標高の精
度が大幅に悪いことにも注目してもらいたい。このこ とからも，現地測量に際して，位置の基準点数より多 くの標高点を設置すべきことがわかる。

目を転じて，国内の測量ならいざしらず，これから の海外への進出を考光る時, 基準点密度の低い未開の 地の大規模な開発に際しては，いやが括うでもブロッ ク調整の問題が出てくる。とりあえづの処置として は，骨幹コースの撮影をすることにより，しのぐこと はできると思うが，モデル単位，コース単位の計算処 理でなく，大容量の計算機を駆使して，ブロック全体

\section{〔計算例〕}

\begin{tabular}{llll}
\multicolumn{3}{c}{ COURSE- 1} \\
\\
N NAME & $P(X Y)$ & $P(H)$ \\
1 & 30121 & 1.0 & 1.0 \\
2 & 30091 & 1.0 & 1.0 \\
3 & 30011 & & 1.0 \\
4 & 30131 & & 1.0 \\
5 & 30181 & & 1.0 \\
5 & 35260 & & 1.0 \\
7 & 35021 & & 1.0 \\
3 & 35030 & & 1.0
\end{tabular}

$y=1: \quad 18027.12$

\begin{tabular}{|c|c|c|c|c|c|c|}
\hline$\Lambda=$ & -0.99678869 & $96 \quad B=$ & $076811 \times 0=$ & 98490.822 & $Y 0=$ & 34893.042 \\
\hline 10 & VAME & $(x)$ & $(D X)$ & $(Y)$ & (DY). & (DS) \\
\hline $\begin{array}{l}1 \\
2\end{array}$ & $\begin{array}{l}30121 \\
30091\end{array}$ & $\begin{array}{l}100015.560 \\
119584.670\end{array}$ & $\begin{array}{r}-0.000 \\
0.000\end{array}$ & $\begin{array}{l}34996.530 \\
34712.750\end{array}$ & $\begin{array}{l}0.000 \\
0.000\end{array}$ & $\begin{array}{l}0.000 \\
0.000\end{array}$ \\
\hline & 0.000 & 31 & 0.000 & & & \\
\hline
\end{tabular}

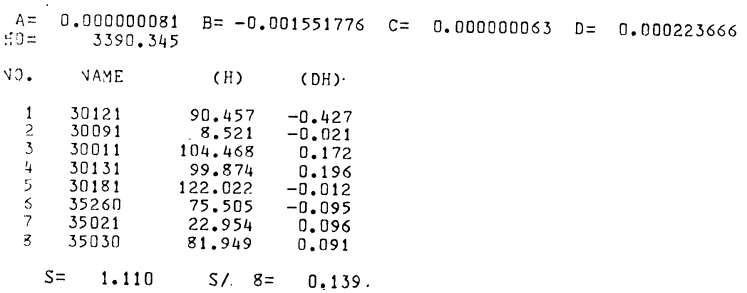

計算例 1.〔B-2〕ブロック組成のための1コースの対地標定 （親コース）

Example of Absolute Orientation of the first strip for Block Construction B-2 


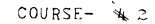

NAME $P(X Y) \quad P(H)$

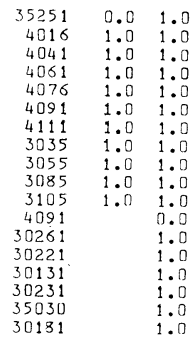

$y=1: \quad 18701.62$

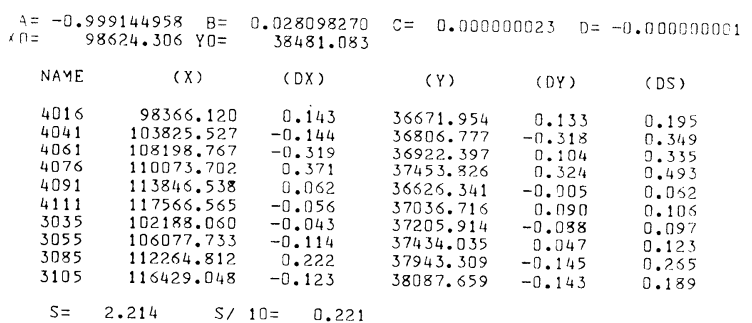

$A=0.000000178 \quad B=-0.003039174 \quad C=0.000000035 \quad D=-0.00001288 ?$

\begin{tabular}{rrr} 
NAME & \multicolumn{1}{c}{$(\mathrm{H})$} & \multicolumn{1}{c}{$(\mathrm{DH})$} \\
35251 & 41.586 & -0.466 \\
4016 & 88.341 & 0.833 \\
4041 & 5.174 & -1.668 \\
4061 & 57.841 & 0.399 \\
4076 & 67.303 & 0.991 \\
4091 & 60.436 & 1.250 \\
4111 & 80.797 & 0.425 \\
3035 & 81.822 & -2.242 \\
3055 & 47.682 & 0.029 \\
3085 & 101.317 & 0.050 \\
3105 & 101.423 & -0.121 \\
30251 & 508.138 & 0.342 \\
30221 & 77.566 & -0.576 \\
30131 & 98.787 & 1.283 \\
30231 & 73.799 & 0.761 \\
35030 & 81.800 & 0.240 \\
30181 & 123.540 & -1.530
\end{tabular}

$S=13.207 \quad$ S/ $17=0.777$

計算例 $2 . 〔 \mathrm{~B}-2 〕 フ ゙ ロ ッ ク$ 組成のための 2 コースの対地 標定 (C-1 に接続した)

Connection between the first strip and the second in B-2

を一度に解くようなシステム開発とか, 撮影の時点 で, 地上ステーションからの撮影点座標の自動観測, 写真傾斜の測定等々, 新らしい技術の開発を進めて行 く必要があると思う。
COURSE- $\ 3$

NAME $P(X Y) \quad P(H)$

$352510.0 \quad 1.0$

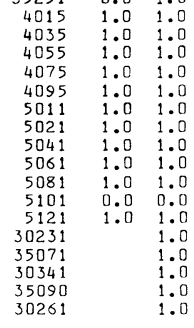

$y=1: \quad 17403.12$ $\begin{aligned} A & =-0.999358737 \quad B= \\ x J & =-98568.577 \quad Y 0=\end{aligned}$

$\begin{array}{llllll}\text { NAME } & (X) \quad(D X) & (Y) & (D Y) & \text { (DS) }\end{array}$

$\begin{array}{lrrrrr}4015 & 98398.840 & 0.229 & 40767.591 & -0.171 & 0.286\end{array}$

$\begin{array}{rrrrrr}4035 & 101876.680 & -0.242 & 40667.422 & 0.036 & 0.245 \\ 4055 & 105594.559 & 0.036 & 40934.166 & -0.323 & 0.325\end{array}$

$\begin{array}{llllll}4075 & 109314.918 & 0.594 & 40813.227 & -0.772 & 0.974\end{array}$

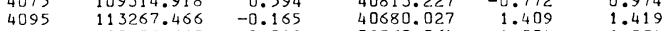

$\begin{array}{llllll}4095 & 98585.683 & 0.012 & 39860.064 & 1.354 & 1.419 \\ 5011 & 980637.780 & 0.013 & 39737.111 & -0.683 & 0.354\end{array}$

$\begin{array}{llrlll}5021 & 100637.780 & 0.013 & 39737.111 & -0.683 & 0.083 \\ 5041 & 104503.791 & -0.714 & 40327.314 & -0.905 & 1.052\end{array}$

$\begin{array}{llllll}5061 & 107866.245 & 0.243 & 40194.655 & -0.953 & 0.984\end{array}$

$\begin{array}{rrrrrr}5081 & 111681.077 & 0.021 & 40065.446 & 2.153 & 2.153 \\ 5121 & 118385.716 & -0.028 & 40629.632 & -1.145 & 1.145\end{array}$
$S=10.720 \quad S / 11=0.975$

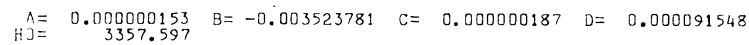

\begin{tabular}{rrr} 
NAYE & \multicolumn{1}{c}{$(\mathrm{H})$} & \multicolumn{1}{c}{$(\mathrm{DH})$} \\
35251 & 40.557 & 0.563 \\
4015 & 7.663 & -0.101 \\
4035 & 7.899 & 0.113 \\
4055 & 56.589 & -0.637 \\
4075 & 35.598 & -0.019 \\
4095 & 209.243 & -0.936 \\
5011 & 9.246 & 0.143 \\
5021 & 70.588 & 0.244 \\
5041 & 2.530 & -0.258 \\
5061 & 49.789 & 0.455 \\
5081 & 131.157 & 0.368 \\
5121 & 321.732 & 0.996 \\
30231 & 74.784 & -0.224 \\
35071 & 35.456 & -0.466 \\
30341 & 505.086 & -0.146 \\
35090 & 38.369 & 1.131 \\
30261 & 509.704 & -1.224 \\
$5=$ & 8.024 & $\mathrm{~S} / 17=$ \\
$\mathrm{S}=0.472$
\end{tabular}

計算例 3.〔B-2〕ブロック組成のための 3 コースの 対地 標定 (C-2 に接続した)

Connection between the second strip and the Third strip in B-2 
COURSE- 4

NAME $P(X Y) \quad P(H)$

$\begin{array}{rll}35271 & 0.0 & 1.0 \\ 30440 & 0.0 & 1.0 \\ 5035 & 1.0 & 1.0 \\ 5055 & 1.0 & 1.0 \\ 5075 & 1.0 & 1.0 \\ 5095 & 1.0 & 1.0 \\ 5115 & 1.0 & 1.0 \\ 5125 & 1.0 & 1.0 \\ 5135 & 1.0 & 1.0 \\ 6021 & 1.0 & 1.0 \\ 6041 & 1.0 & 1.0 \\ 6061 & 1.0 & 1.0 \\ 6081 & 1.0 & 1.0 \\ 6101 & 1.0 & 1.0 \\ 35071 & & 1.0 \\ 35271 & & 0.0 \\ 30440 & & 0.0 \\ 35090 & & 1.0 \\ 30401 & & 1.0\end{array}$

$y=1: \quad 19923.09$
COURSE-210

NAME $P(X Y) \quad P(H)$

$\begin{array}{lll}30091 & 1.0 & 1.0 \\ 30121 & 1.0 & 1.0 \\ 35251 & 1.0 & 1.0 \\ 35251 & 1.0 & 1.0 \\ 35271 & 1.0 & 1.0 \\ 30440 & 1.0 & 1.0 \\ 30091 & & 0.0 \\ 30440 & & 0.0 \\ 30221 & & 1.0 \\ 30011 & & 1.0 \\ 30131 & & 1.0 \\ 35021 & & 1.0 \\ 35260 & & 1.0 \\ 35030 & & 1.0 \\ 30181 & & 1.0 \\ 30131 & & 1.0 \\ 30231 & & 1.0 \\ 35030 & & 1.0 \\ 30181 & & 1.0 \\ 30261 & & 1.0 \\ 30231 & & 1.0 \\ 35071 & & 1.0 \\ 35090 & & 1.0 \\ 30261 & & 1.0 \\ 30341 & & 1.0 \\ 35071 & & 1.0 \\ 35090 & & 1.0 \\ 30401 & & 1.0\end{array}$

$\begin{array}{rrr}A=-0.997314959 & B= & 0.084815040 \\ X D= & 99705.051 Y O= & 45329.843\end{array}$

NAME $(X) \quad(D X)$

(Y) (DY)

(DS)

$\begin{array}{rrr}5035 & 102287.402 & 0.739 \\ 5055 & 105715.791 & -1.374 \\ 5075 & 110130.492 & -0.569 \\ 5095 & 112841.290 & 1.109\end{array}$

$43714.748-0.380$

$\begin{array}{ll}44048.463 & 0.707 \\ 44133.703 & 1.810\end{array}$

$\begin{array}{lllll}5115 & 116516.563 & 0.589 & 44228.620 & -0.243\end{array}$

$\begin{array}{rrrrr}5125 & 118472.404 & 0.104 & 43981.159 & -0.341 \\ 5135 & 120072.335 & -1.343 & 44483.898 & -0.658\end{array}$

$\begin{array}{rrrrr}5135 & 120072.335 & -1.343 & 44483.898 & -0.658 \\ 6021 & 100001.710 & 0.725 & 43212.965 & 0.734\end{array}$

$6041 \quad 104079.052 \quad-0.327 \quad 43311.414 \quad-0.865$

$6061-107537.438-1.548 \quad 43737.752-0.941$

$6081 \quad 111329.783 \quad 0.801 \quad 43706.018 \quad-1.126$

$S=14.426 \quad S / 12=1.20 ?$.

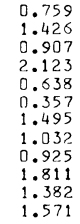

1.426

0.907
2.123

.038

1.495

1.032
0.925

1.382

1.571

$y=1: \quad 999.9 / 4$ $\begin{array}{rrr}A=-1.000105575 & B=-0.000395362 \\ X O= & C=-0.000000038 \quad D=-0.0000000008 \\ 108997.559 & Y 0= & 39781.579\end{array}$

\begin{tabular}{rcrrrl} 
NAME & $(X)$ & $(D X)$ & $(Y)$ & \multicolumn{1}{c}{$(D Y)$} & $(D S)$ \\
30091 & 119586.205 & -1.535 & 34713.830 & -1.080 & 1.877 \\
30121 & 100015.760 & -0.200 & 34997.873 & -1.343 & 1.358 \\
35251 & 109628.429 & 0.241 & 40064.531 & 0.339 & 0.416 \\
35251 & 109627.893 & 0.777 & 40065.119 & -0.249 & 0.816 \\
35271 & 101063.588 & 1.052 & 46036.949 & 0.701 & 1.264 \\
30440 & 120337.844 & -0.334 & 45685.508 & 1.632 & 1.666
\end{tabular}

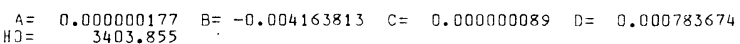
$S=7.397$ S/ $\sigma=1.233$

\begin{tabular}{rrr} 
NAME & $(\mathrm{H})$ & \multicolumn{1}{c}{$(\mathrm{DH})$} \\
35271 & 23.498 & -0.168 \\
30440 & 288.814 & 0.846 \\
5035 & 23.700 & 0.166 \\
5055 & 25.068 & 0.890 \\
5075 & 40.468 & -0.992 \\
5095 & 143.380 & -1.752 \\
5115 & 334.444 & -1.249 \\
5125 & 337.270 & 1.511 \\
5135 & 129.724 & -1.654 \\
6021 & 22.927 & 0.164 \\
6041 & 2.222 & 0.046 \\
6061 & 37.809 & -0.398 \\
6081 & 97.951 & -0.597 \\
6101 & 220.298 & 2.008 \\
35071 & 35.898 & -0.908 \\
35090 & 38.473 & 1.027 \\
30401 & 25.791 & 1.069
\end{tabular}

$S=15.456 \quad S / 17=0.909$

計算例 4.〔B-2〕ブロック組成のための 4 コースの対地 標定 (C-3 に接続した)

Connection between the third strip and the fourth strip in B-2
$A=-\begin{array}{r}A .000000004 \\ 0.231\end{array} \quad B=-0.000051849 \quad C=-0.000000009 \quad D=0.000037143$

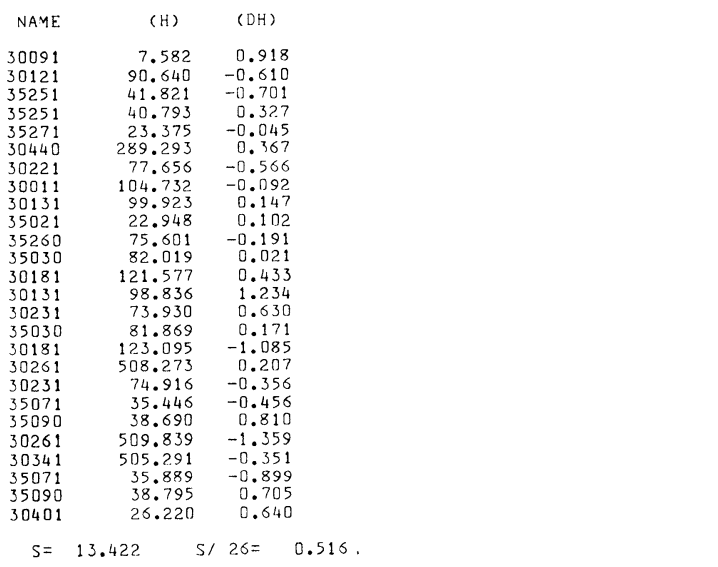

計算例 5.〔B-2〕プロック対地標定

位置は 2 次等角写像変換, 標高は 5 元 2 次

Absolute Orientation of Block B-2 
COURSE-2.10

TABLE OF TIEPOINT DIFFERENCE

NAME $(X) \quad(Y)$.

3) 011 -T

$\begin{array}{rr}30011-T & 9942.0 .87 \\ 30031-T & 101753.24\end{array}$

$30041-\mathrm{T} \quad 107114.55$

$3051-T \quad 106183.23$

$\begin{array}{ll}30061-T & 112364.09 \\ 3.0071-\mathrm{T} & 115734.96\end{array}$

$30091-\mathrm{T} \quad 119586.20$

$30121-\mathrm{T} \quad 100015.76$

20141-T 102462.66

$30151-\mathrm{T} \quad 104826.94$

$30161-1 \quad 112887.23$

$30171-\mathrm{T} \quad 115559.06$

$30181-\mathrm{T} \quad 118302.54$

$30221-\mathrm{T} \quad 99367.54$

S0231-T 102958.80

$\begin{array}{ll}30241-\mathrm{T} & 107801.55 \\ 30261-\mathrm{T} & 115000.48\end{array}$

$30271-\mathrm{T} \quad 119824.5$

$\begin{array}{ll}30311-T & 108552.35 \\ 30321-T & 110630.70\end{array}$

$\begin{array}{ll}33321-\mathrm{T} & 110630.70 \\ 30331-\mathrm{T} & 116319.08\end{array}$

$\begin{array}{ll}30331-T & 116319.08 \\ 30341-T & 119211.33\end{array}$

$\begin{array}{ll}30391-T & 104955.95 \\ 33401-T & 108256.78\end{array}$

$\begin{array}{ll}\text { 3) } 301-T & 108256.78 \\ 33431-T & 117362.10\end{array}$

$\begin{array}{ll}33431-T & 117362.10 \\ 30440-T & 120337.84\end{array}$

$\begin{array}{ll}30440-T & 120337.84 \\ 35021-T & 108847.00\end{array}$

$35030-T \quad 110774.24$

$35041-T \quad 106590.42$

$35071-T \quad 101641.73$

35081-T 104396.

35090-T 107069.75

$35101-\mathrm{T} \quad 11102.2 .08$

35251-T 109627.89

$\begin{array}{ll}35260-T & 108257.53 \\ 35271-T & 101063.59\end{array}$

$(y)$

(H) $($ COJRSE) $(X) \quad(Y) \quad(H) \quad(D X) \quad(D Y)(D X 2)(D Y 2)(D S 2) \quad(D S) \quad(D H)$ 32849.11 33136.80 34681.7 34681.18 34713.83 34713.83 36892.73 37134.85 37320.29 38676.37 38544.56 37499.38 39117.20 39616.9 40977.72 40233.06 42804.11 43513.29
43360.25 45840.15 45587.07 46841.87 45685.51 37429.90 40410.24 43591.50 43792.04 42713.73 43708.44 44776.12 40065.12 35822.60 46036.95 $\begin{array}{rrrrrrrrrrr}104.73110 & 20.84 & 75.58 & 4.64 & 0.03 & 1.2 .0 & 0.00 & 1.43 & 1.43 & 1.20 & 0.09 \\ 96.33110 & 53.28 & 48.30 & 97.10 & -0.04 & 0.81 & 0.00 & 0.66 & 0.66 & 0.81 & -0.77 \\ 25.58110 & 14.90 & 36.67 & 25.31 & -0.35 & 0.13 & 0.12 & 0.02 & 0.14 & 0.37 & 0.27\end{array}$

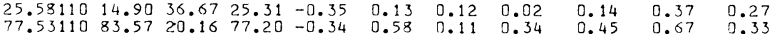

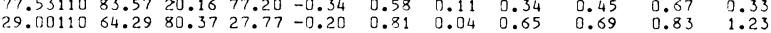

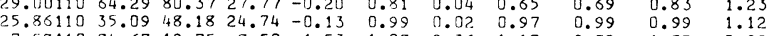

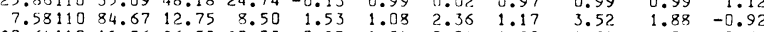

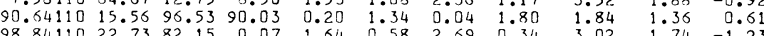

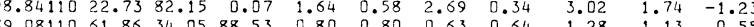

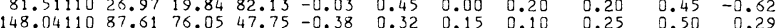

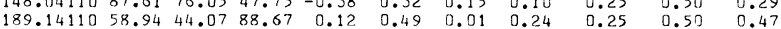

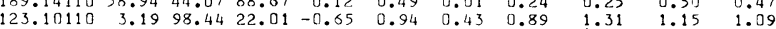

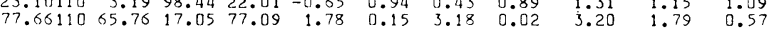

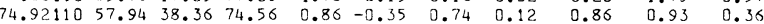

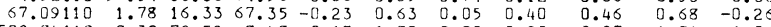

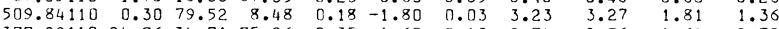

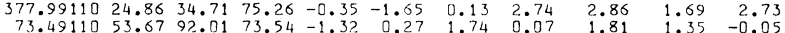

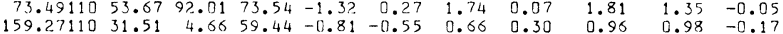

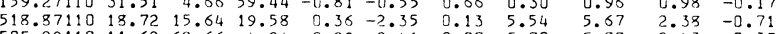

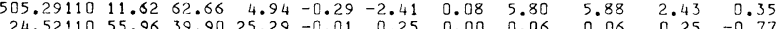

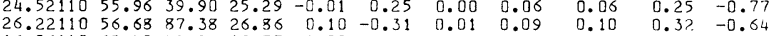

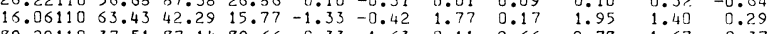

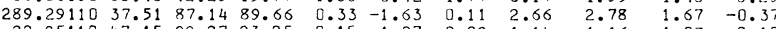

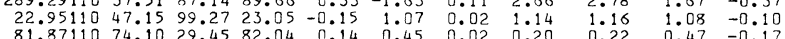

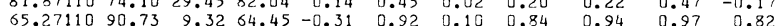

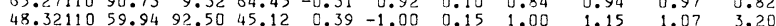

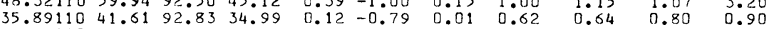

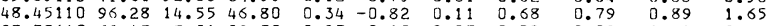

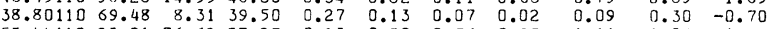

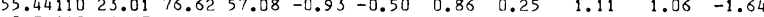

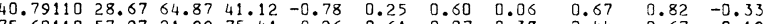
$\begin{array}{llll}0.38 & 0.44 & 0.67 & 0.19\end{array}$

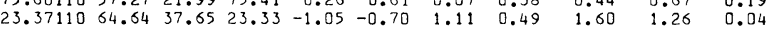

SIGMA $=54.72 \quad 37.97$

$\operatorname{ROOT}($ SIGMA $/ N)=1.20 \cdot 1.00$

$\operatorname{MAX} .=2.43 \quad 3.20$

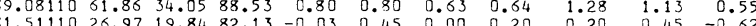

計算例 6. 〔B-2〕のブロック調整結果のチェックポイント残差表

(航三整理のタイポイント較差表プログラムを使用)

Residuals at check point after Block Adjustment B-2 


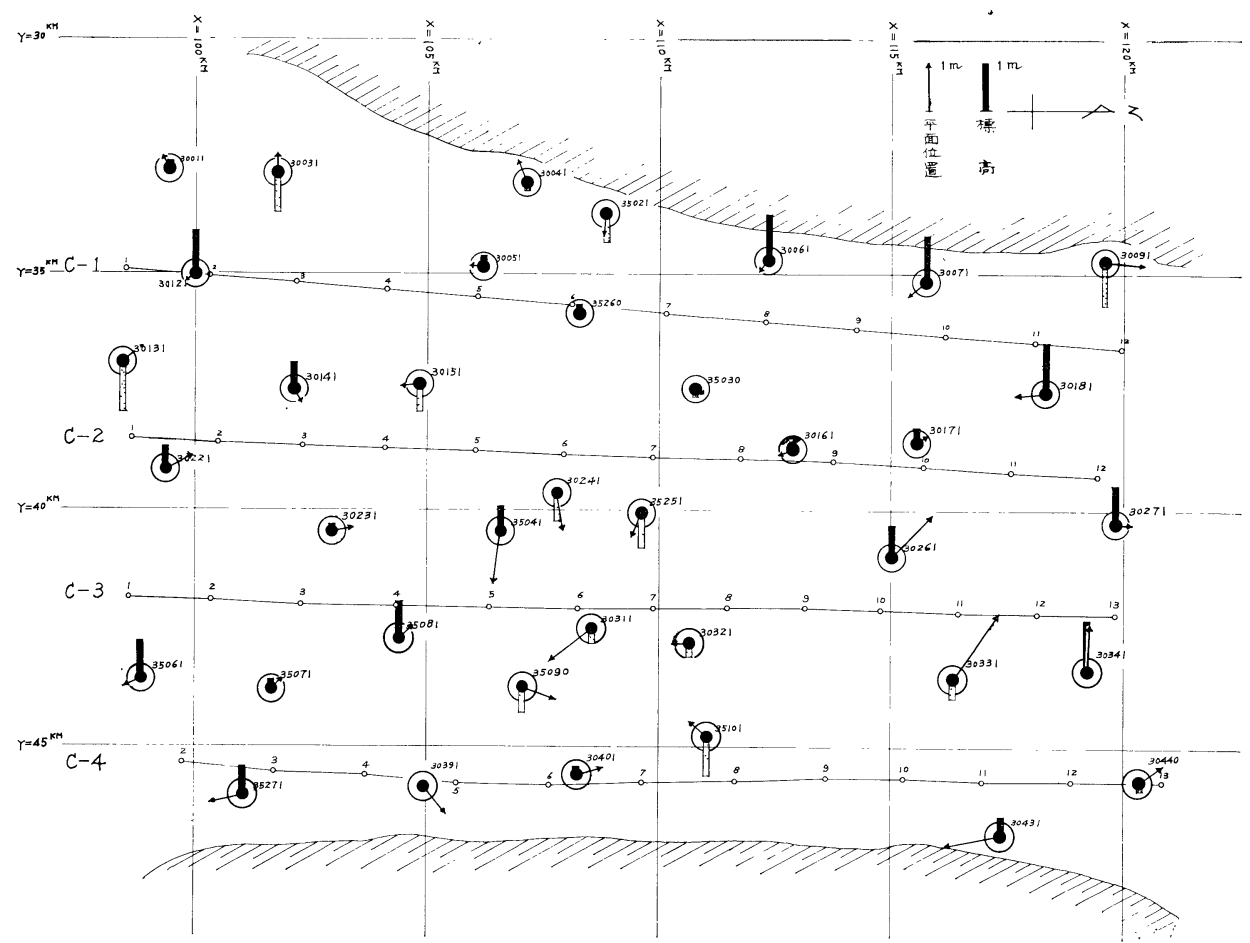

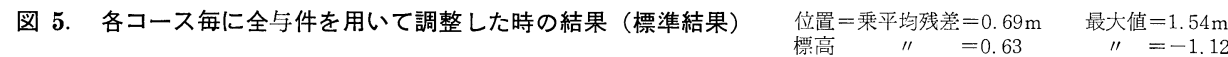
Results of Strip Adjustment with full control points (Standard Case)

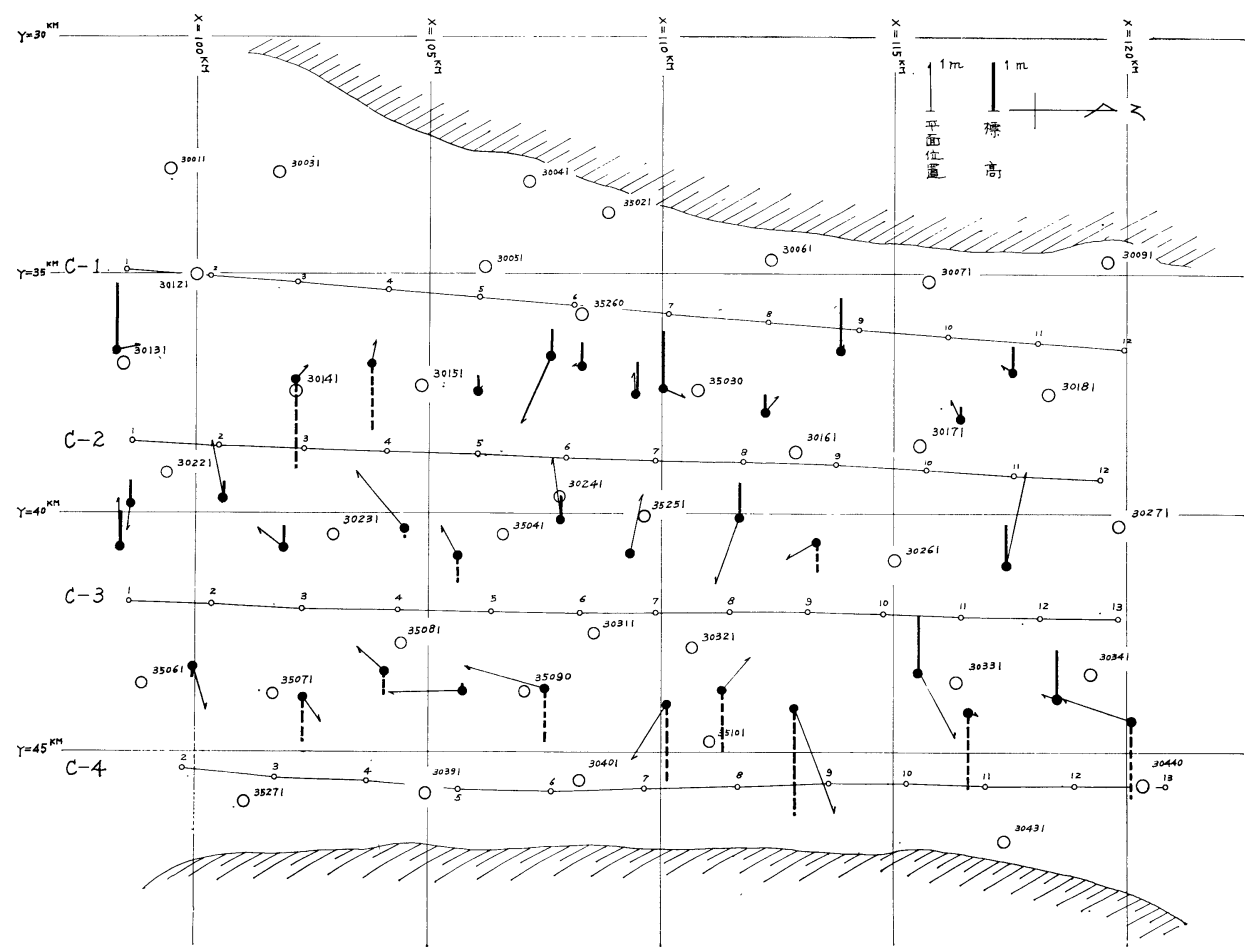

図 6. 標準結果のタイポイント残差 位置の二乗平均残差 $=1.10 \mathrm{~m} \quad$ 最大值 $=2.40 \mathrm{~m}$ Residuals at tie points in the Standard Case 


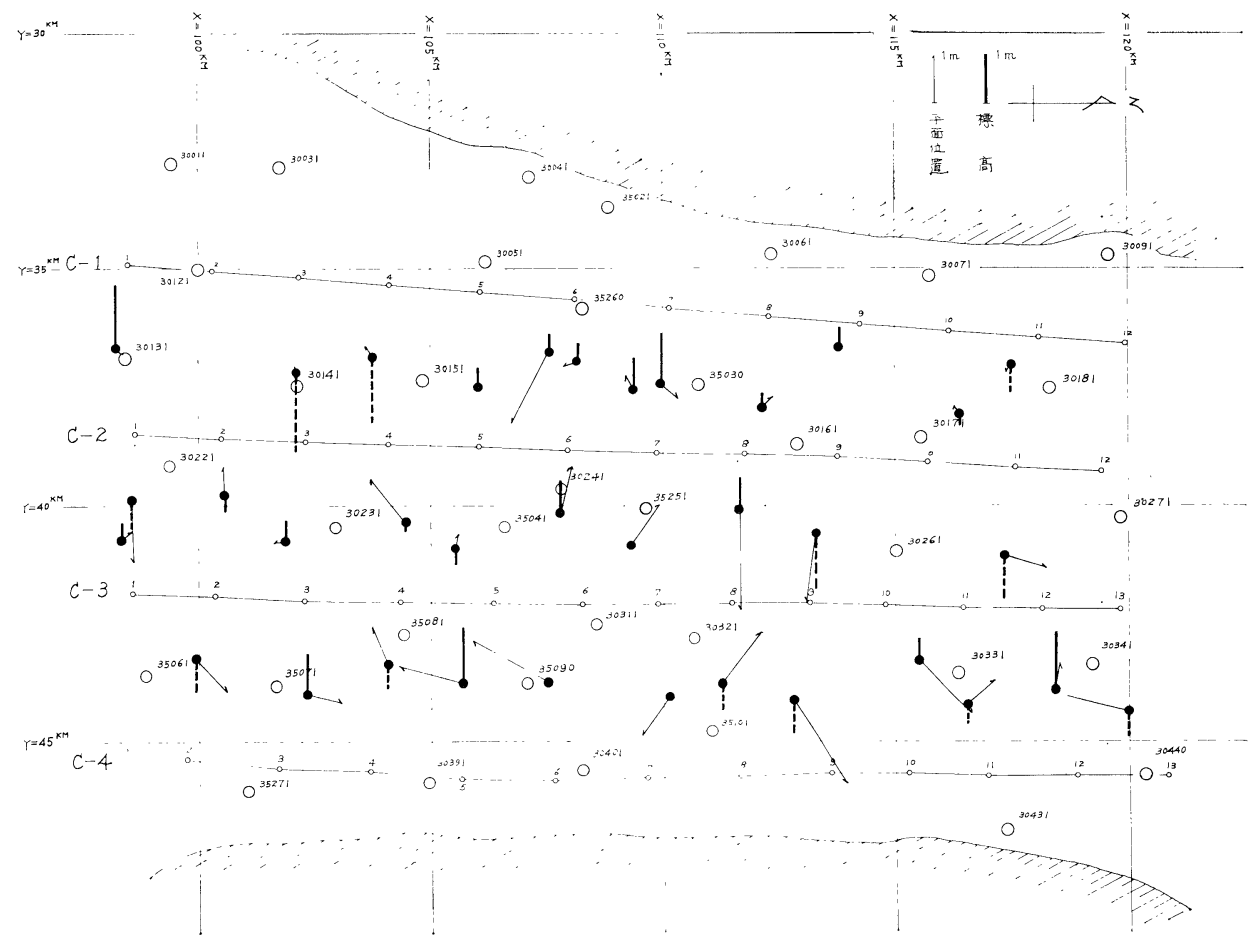

図 7.1コースを親として接続した場合のタイポイント残差〔Aグループブロック組成時〕

位置の二乗平均残差 $=1.03 \mathrm{~m}$ 最大值 $=2.16 \mathrm{~m}$

標高の " $"=0.74 \quad "=-1.69$

Residuals at tie point in the case of A-group
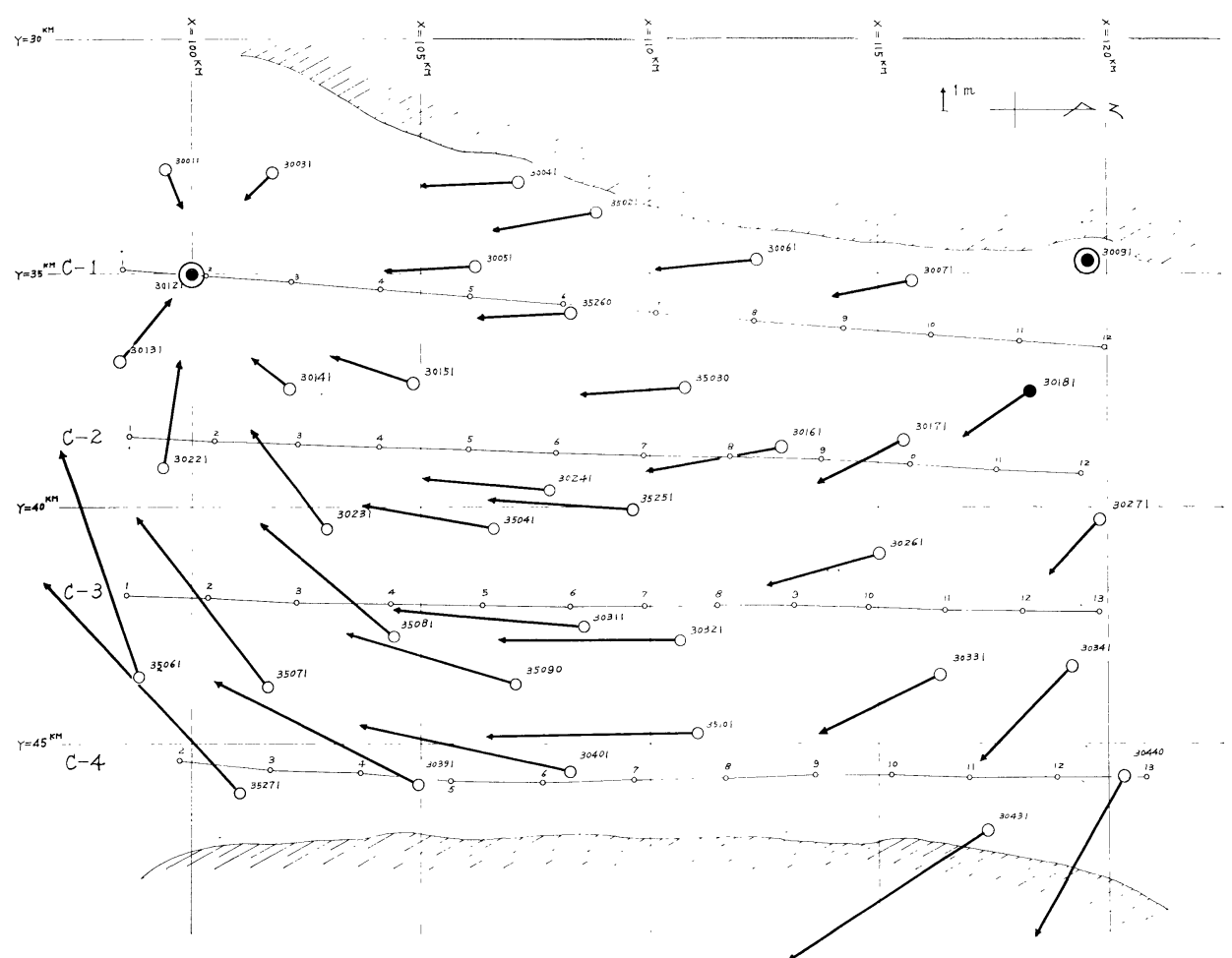

図 8.1コースを親として接続したままのチェックポイントの位置残差

〔Aグループブロック組成時〕位置 二乗平均残差 $=6.31 \mathrm{~m}$ 最大值 $=12.40 \mathrm{~m}$

Residuals at check points in the case of A-group 


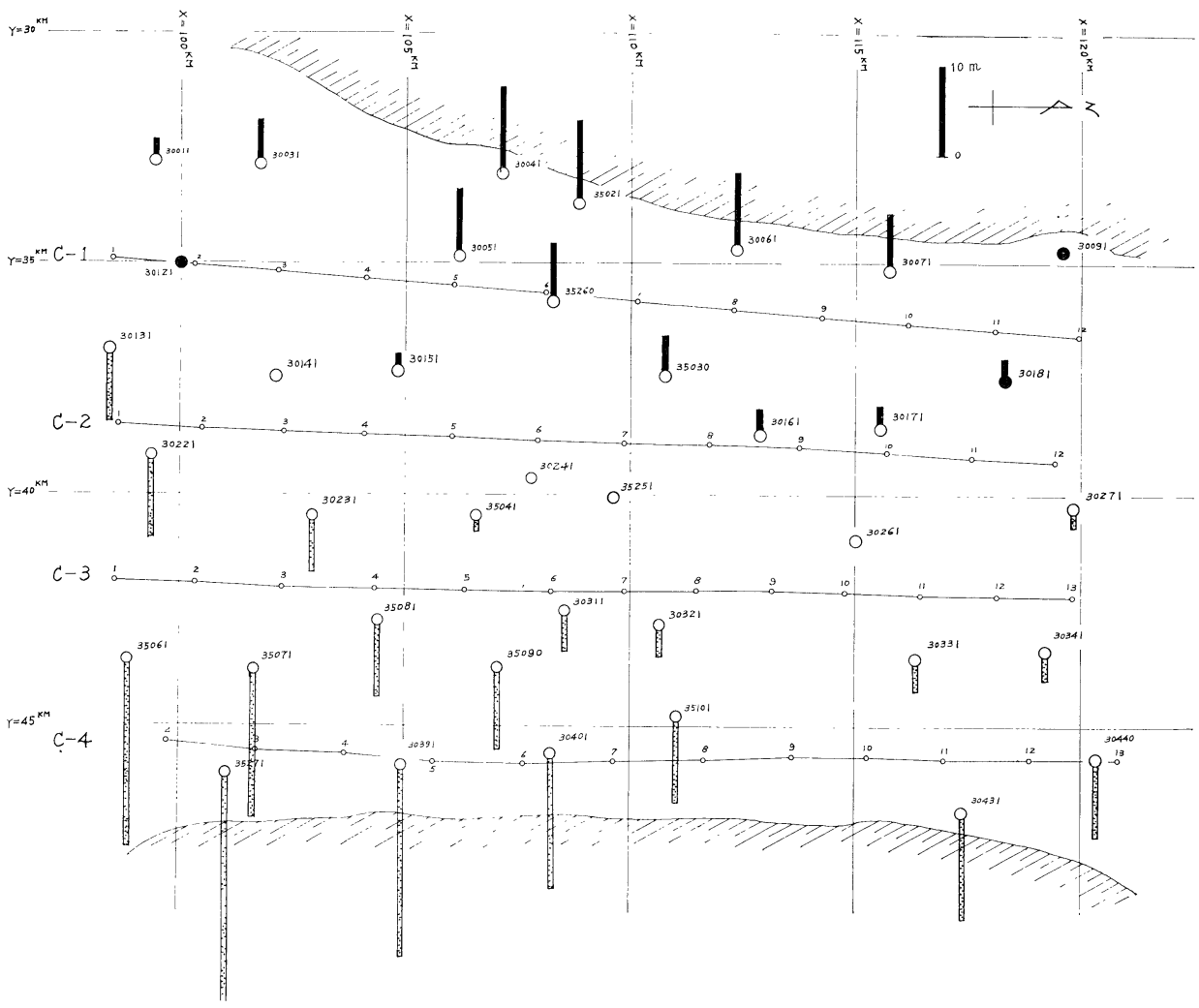

図 9. 1コースを親として接続したままのチェックポイントの標高残差

〔Aグループブロック組成時〕標高 二乗平均残差 $=9.64 \mathrm{~m} \quad$ 最大值 $=-29.69$ Height residuals at each point in A-group

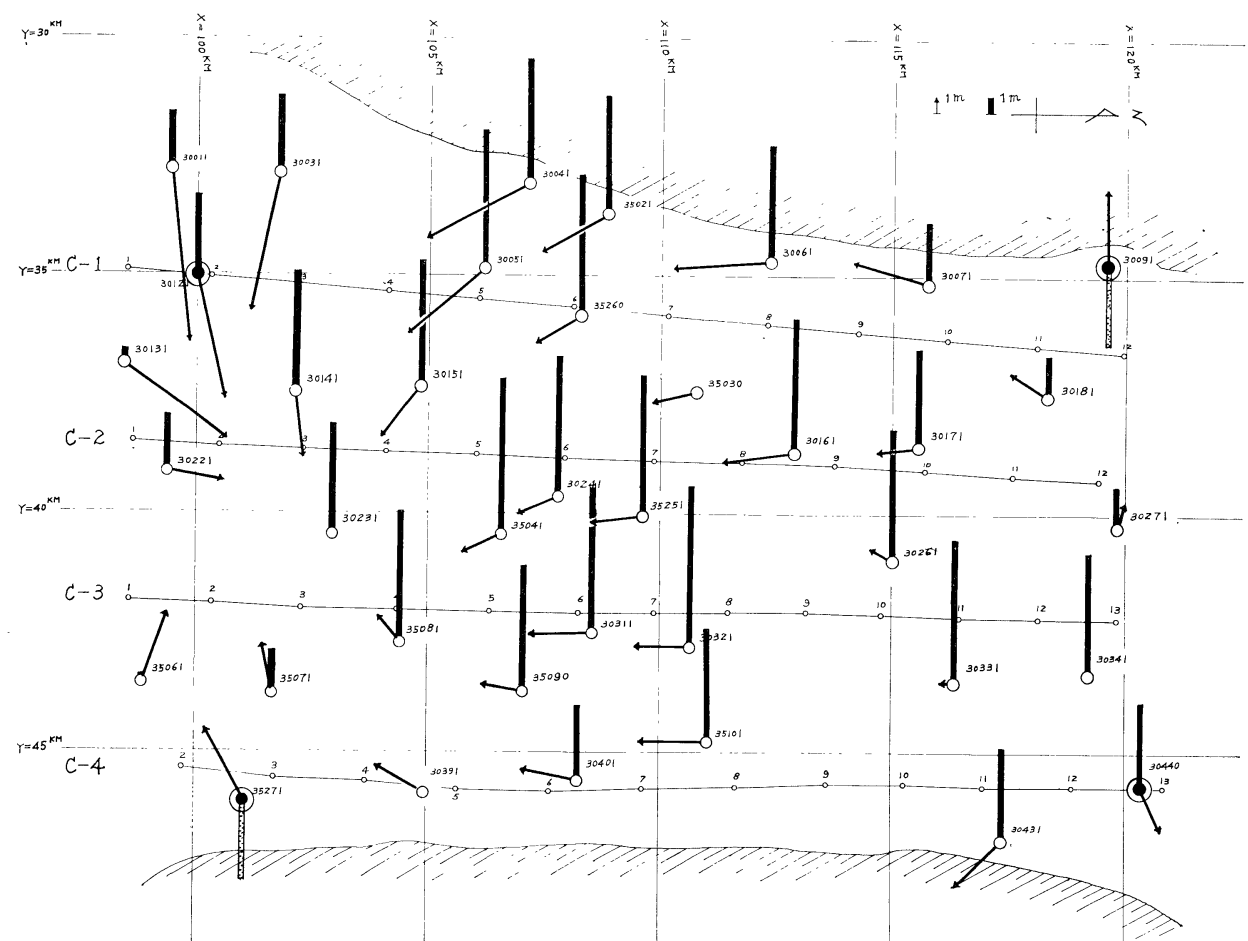

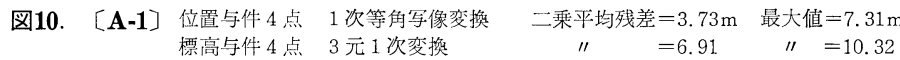
Results of Block Adjustment A-1 

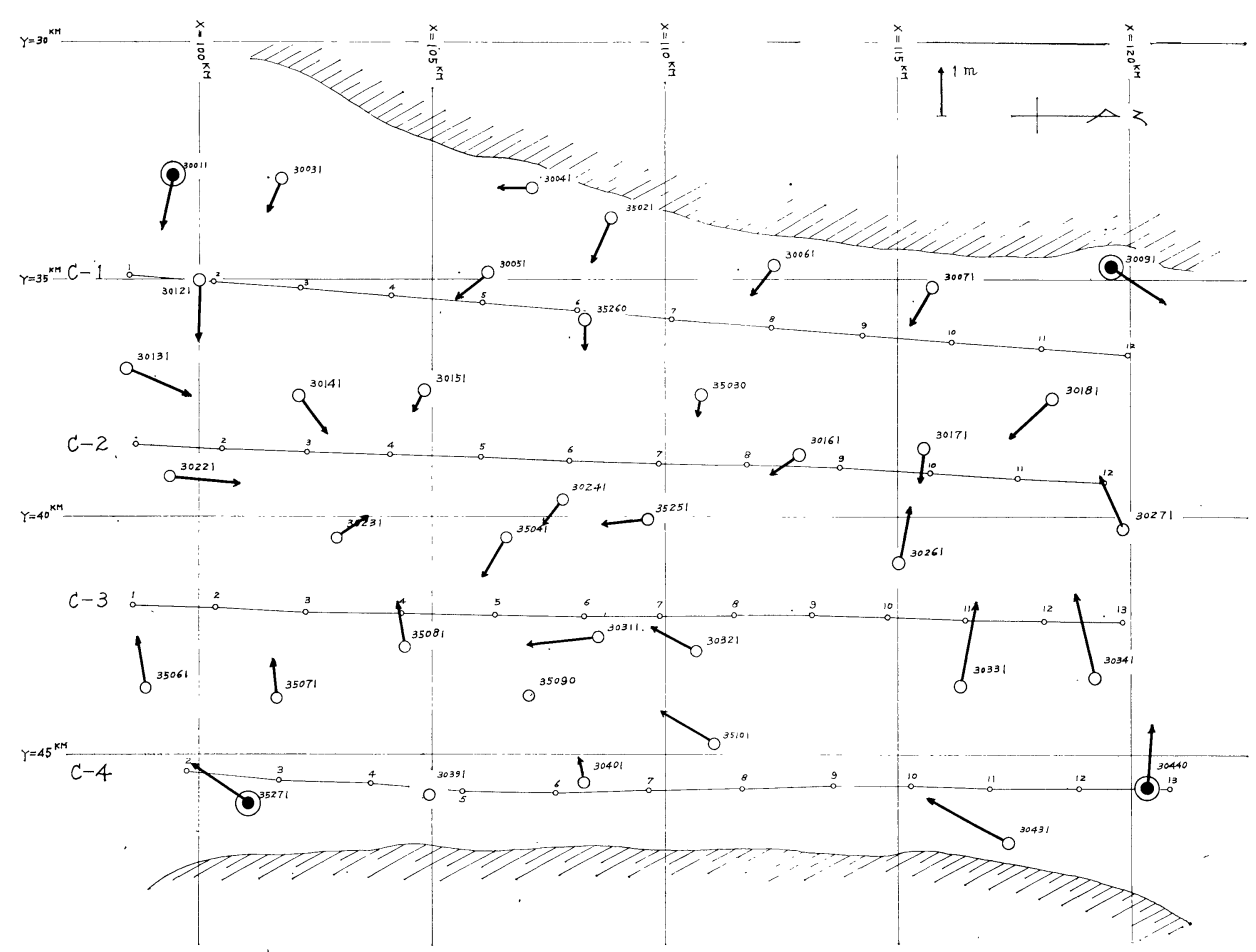

図11.〔A-2〕位置与件 4 点 2 次等角写像変換 二乗平均残差 $=1.11 \mathrm{~m}$ 最大值 $=1.96 \mathrm{~m}$ (高さは[A-1]と同じ)

Results of Block Adjustment A-2

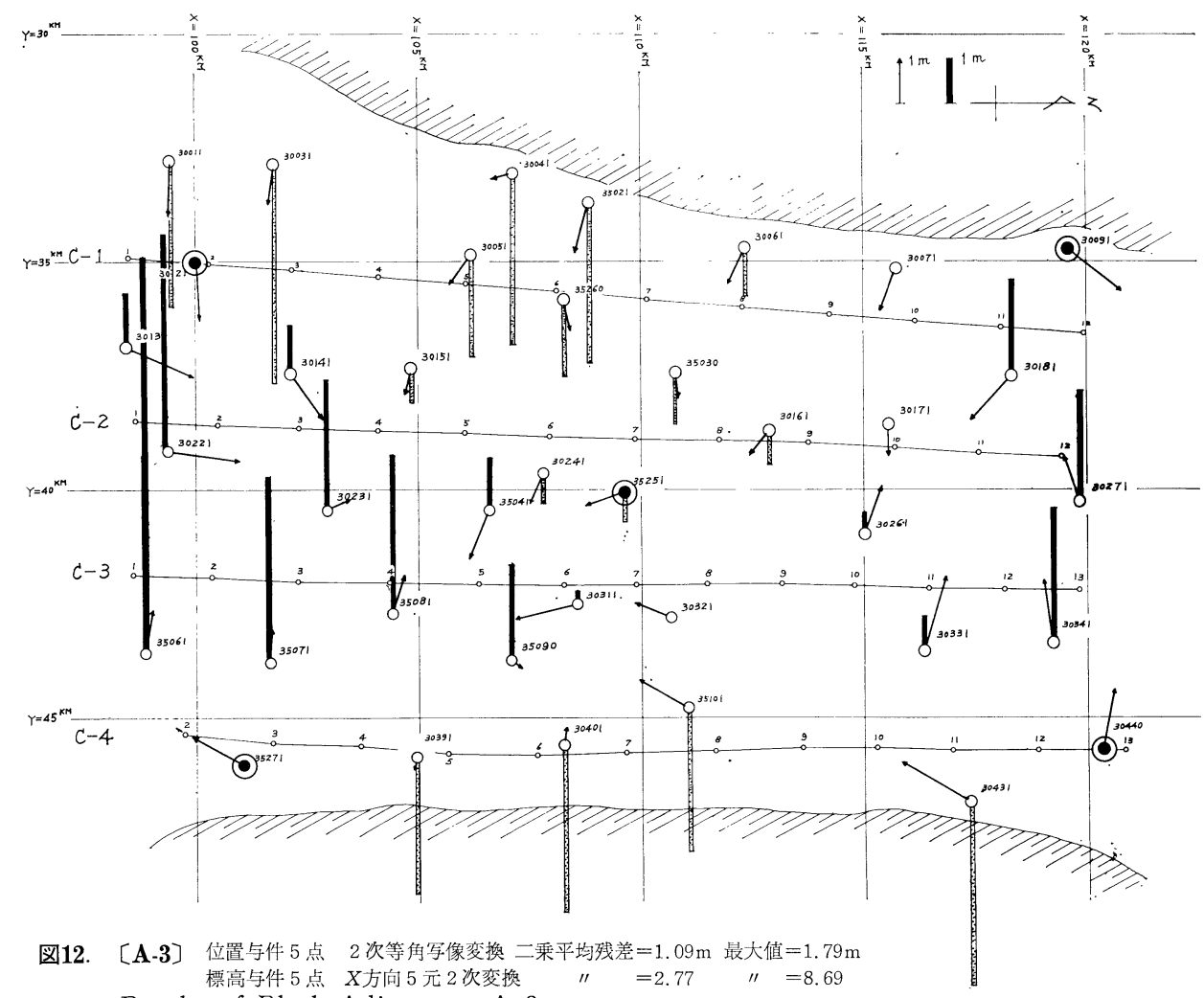
Results of Block Adjustment A-3 


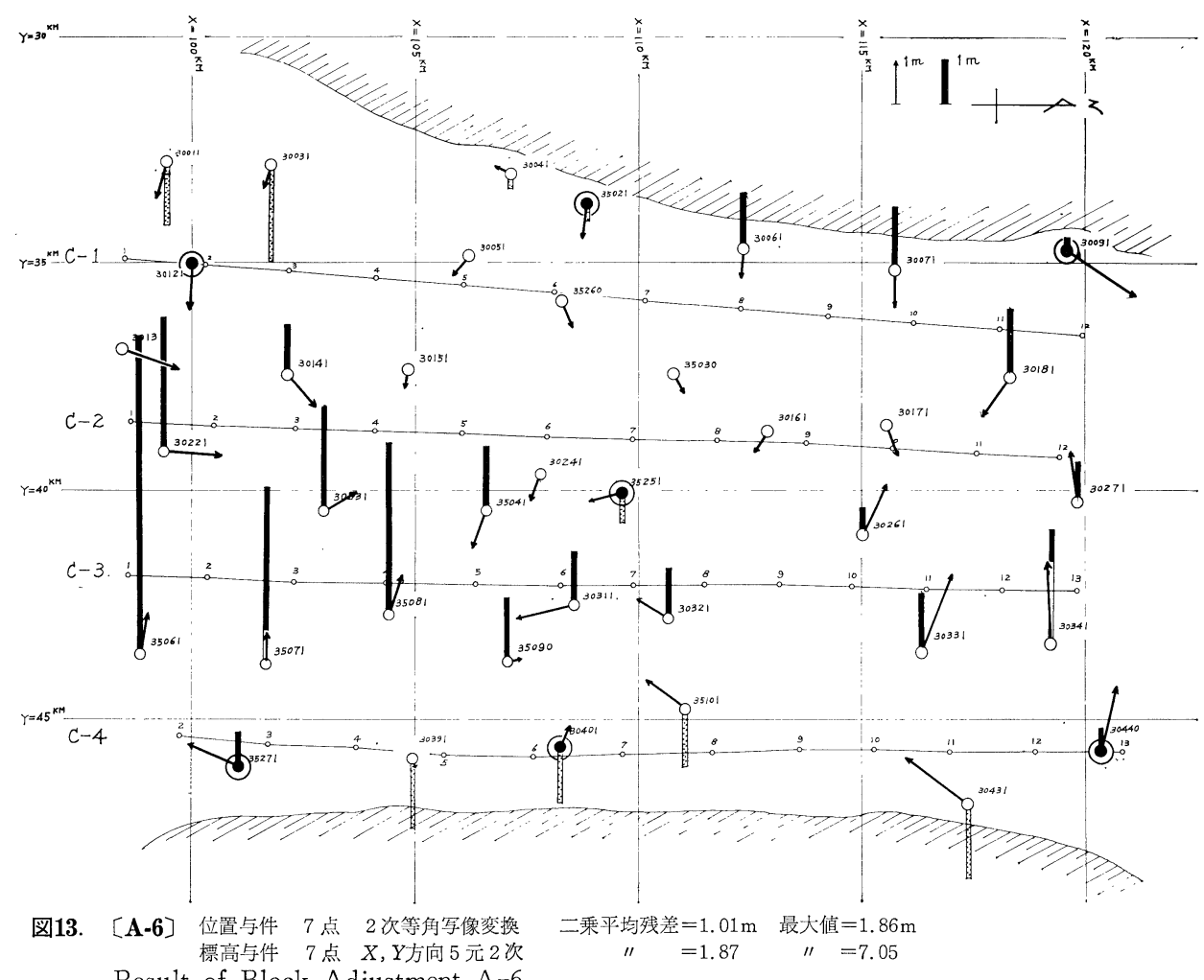

Result of Block Adjustment A-6

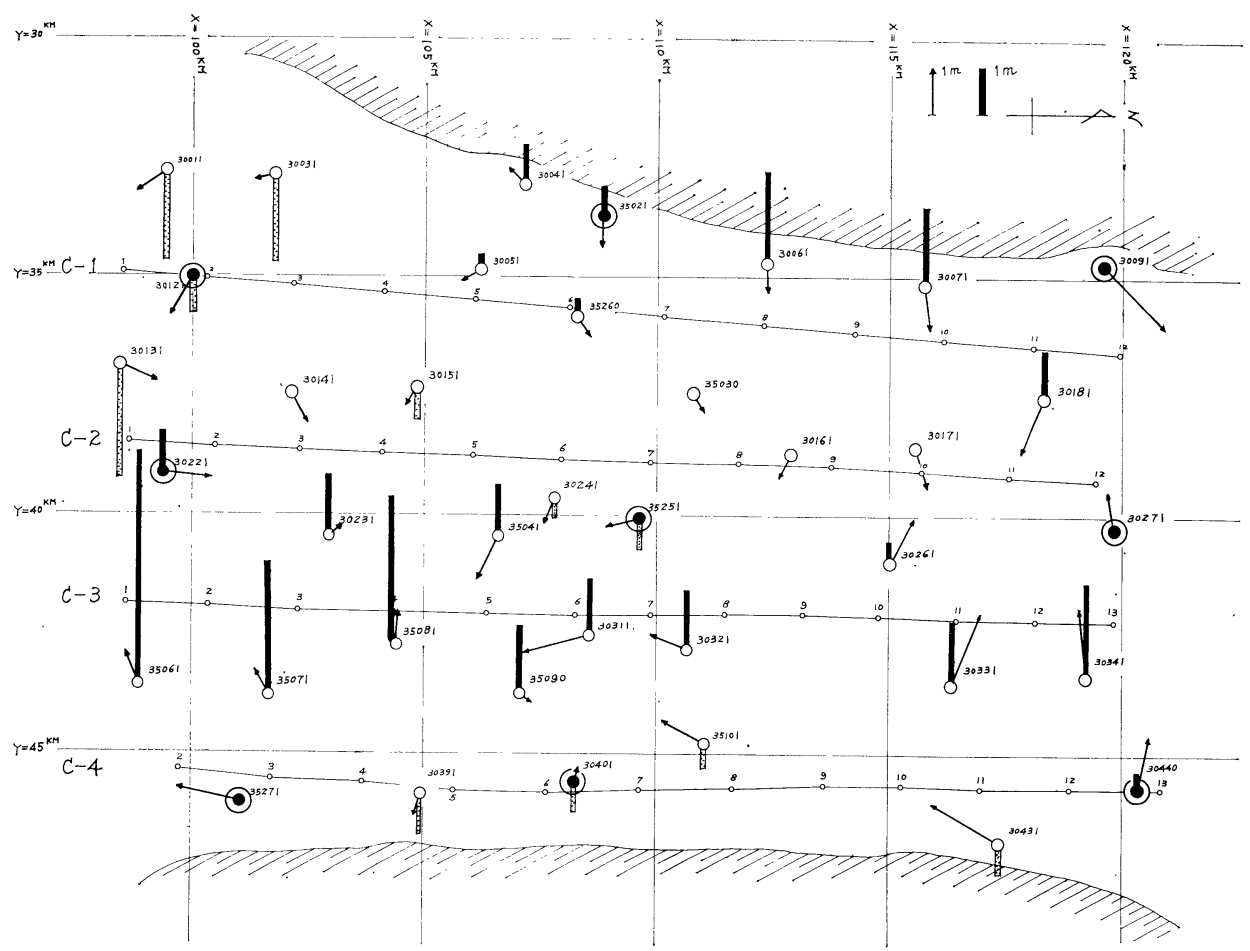

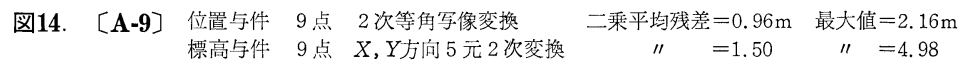

Result of Block Adjustment A-9 


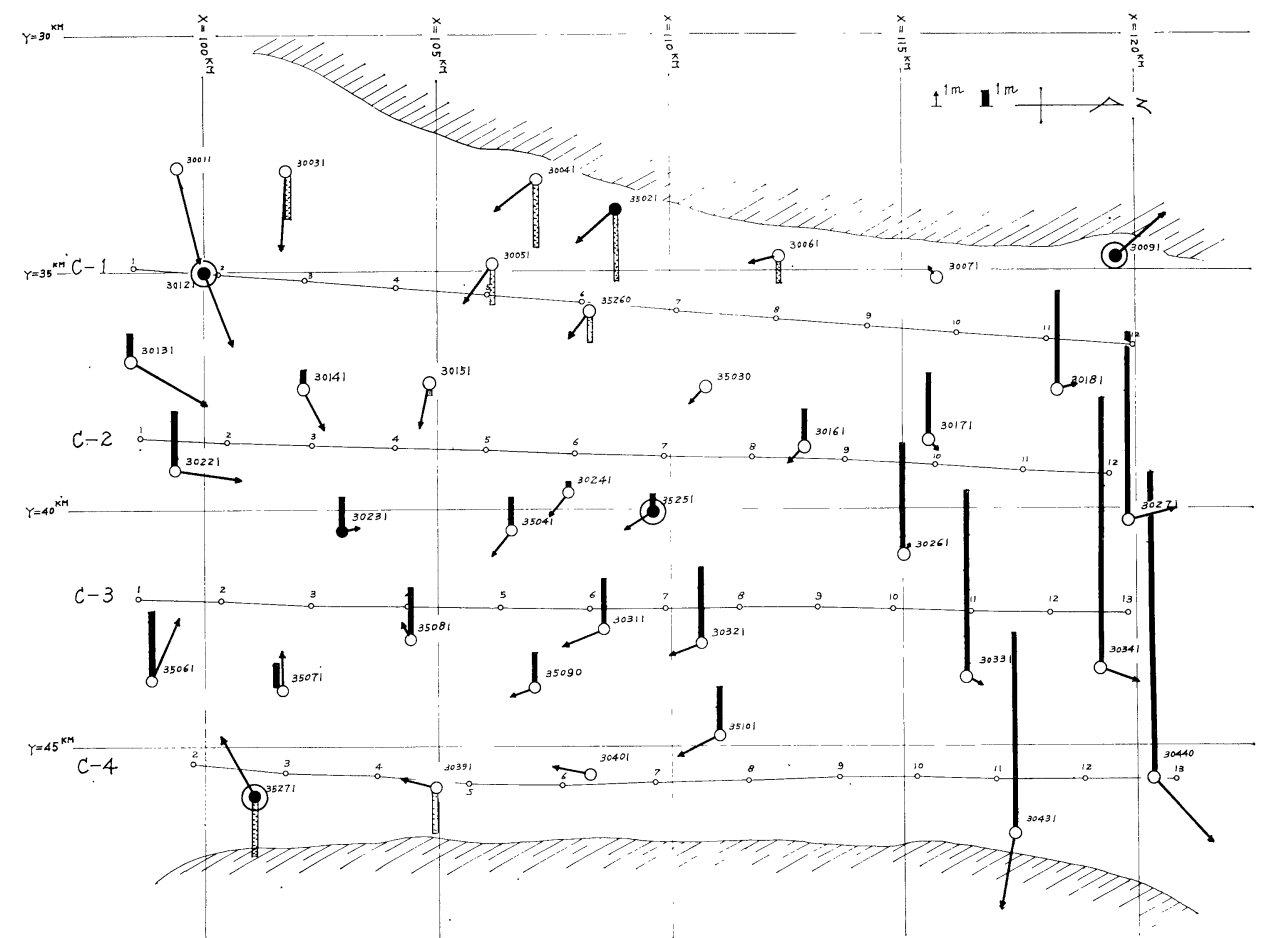

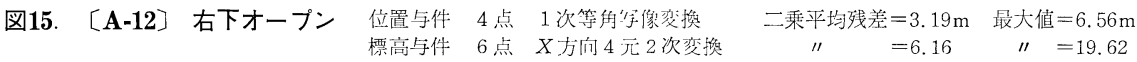
Result of Block Adjustment A-12

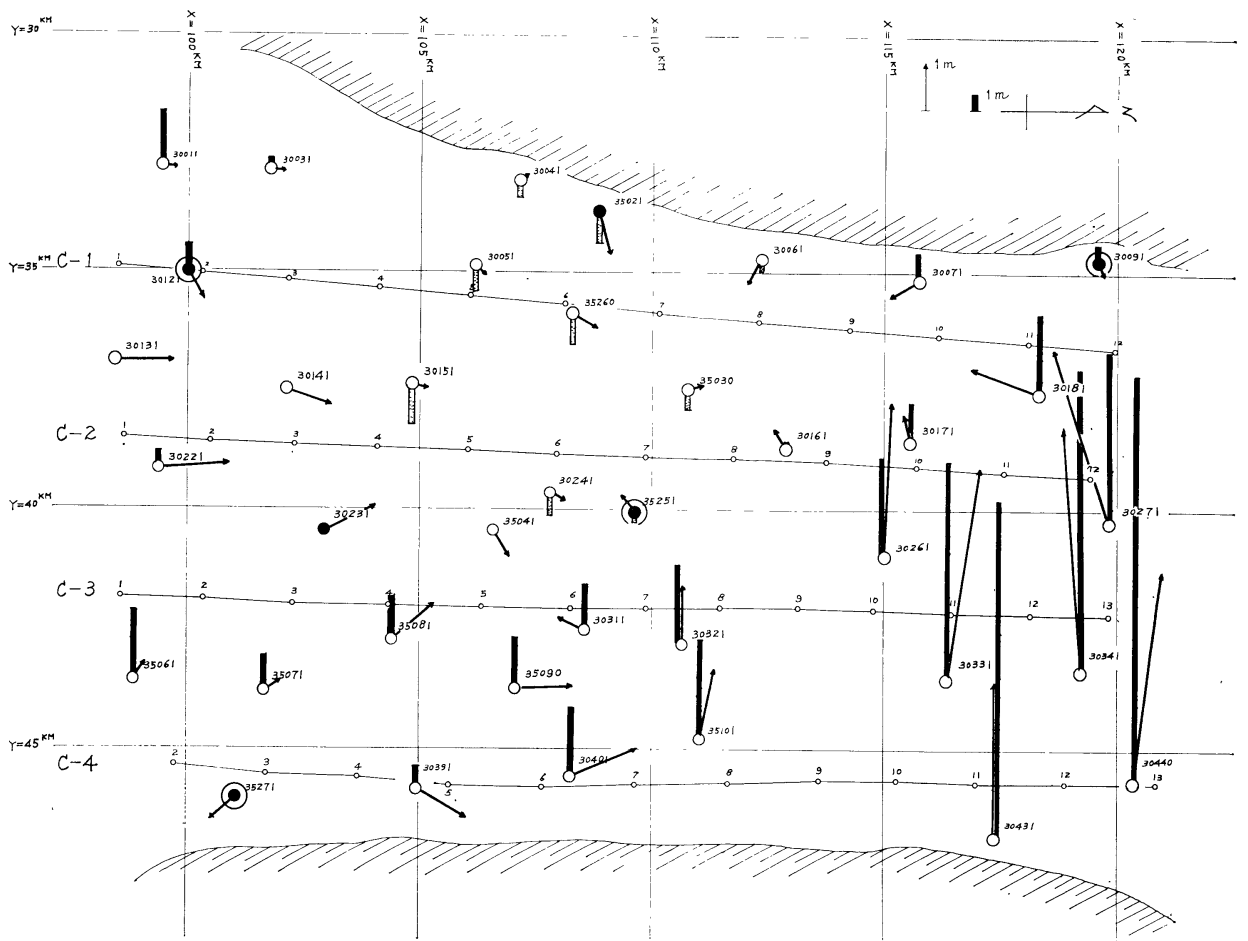

図16.〔A-13〕右下オープン 位置与件 4 点 2 次等角写像变換 二乘平均残差 $=1.89 \mathrm{~m}$ 最大值 $=5.19 \mathrm{~m}$ Result of Block Adjustment A-13 


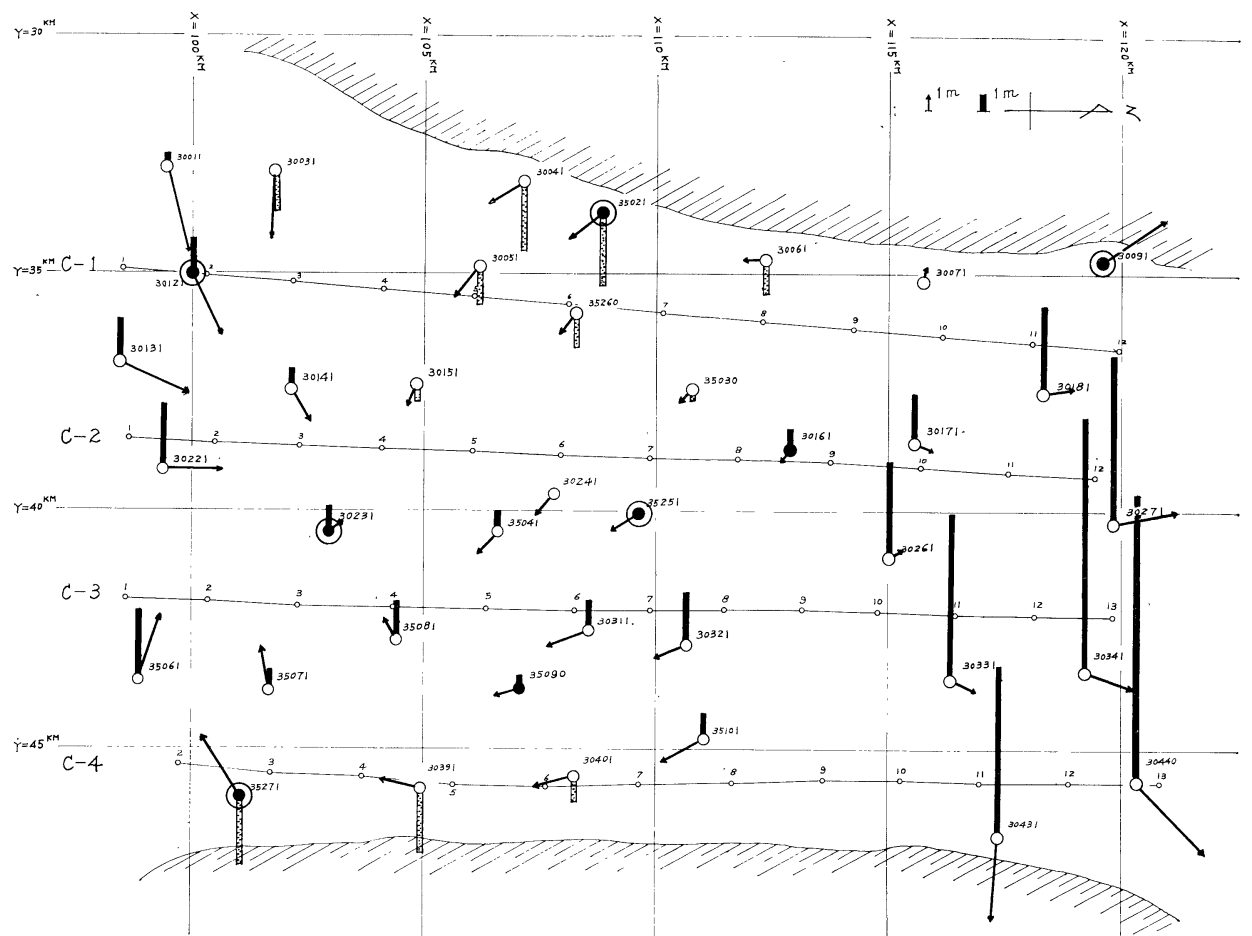

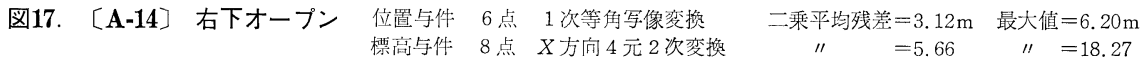
Result of Block Adjustment A-14

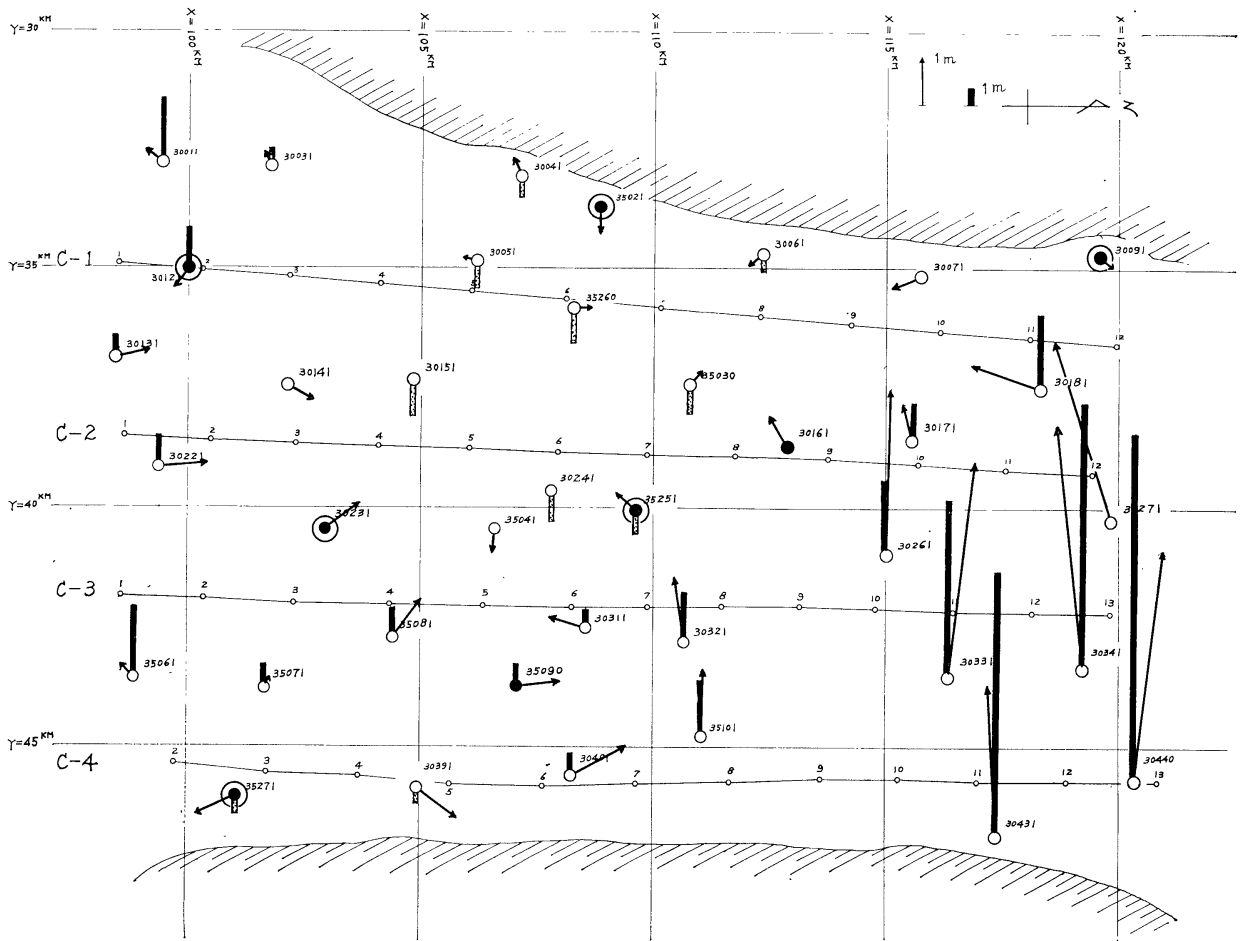

図18.〔A-15〕右下オープン 位置与件 6 点 2 次等角写像変換 二乗平均残差 $=1.85 \mathrm{~m}$ 最大值 $=5.20 \mathrm{~m}$ Result of Blo 標高与件 8 点 $X, Y$ 方向 4 元 2 次変換 $\quad "=6.16 \quad "=22.10$ 


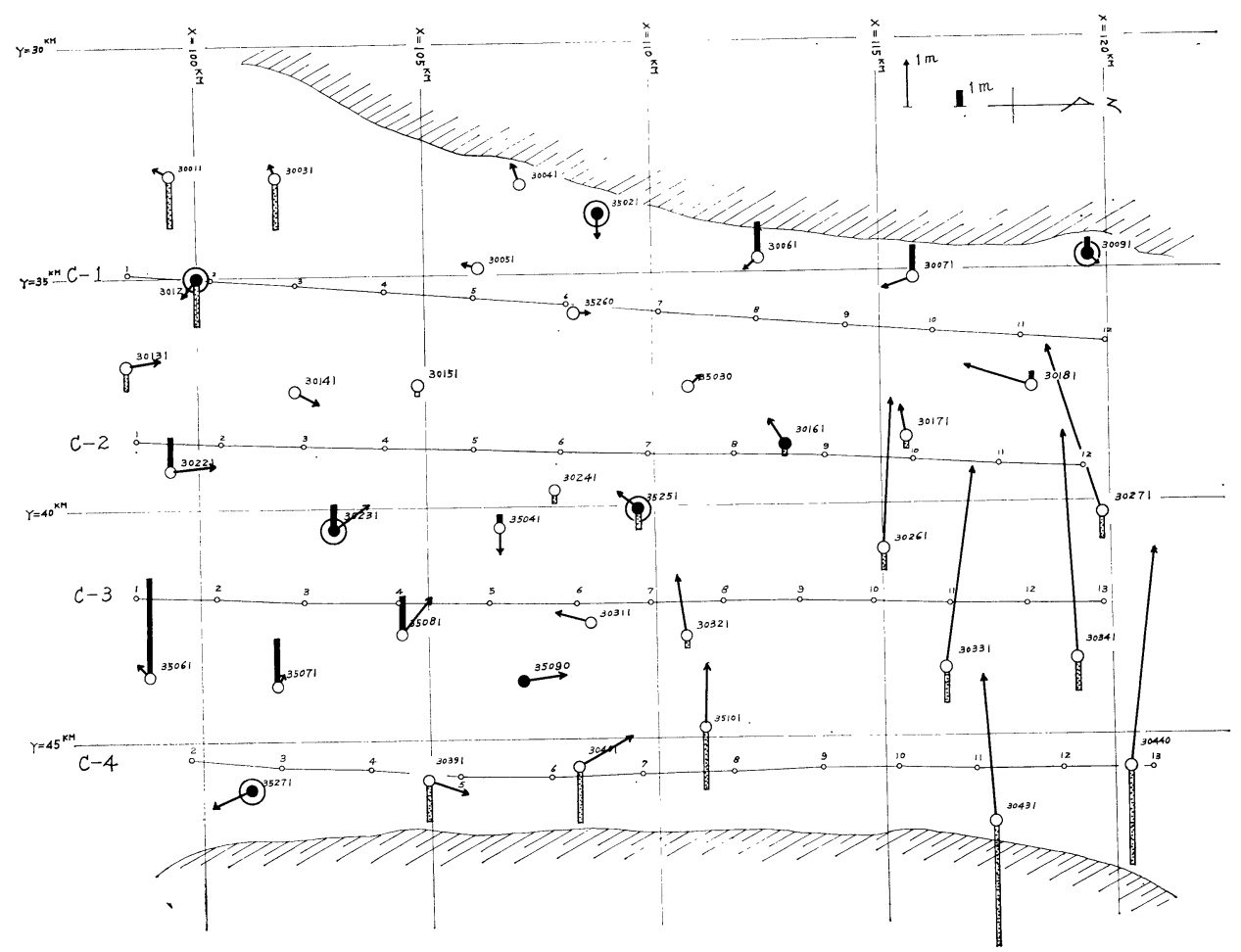

図19.〔A-16〕右下オープン 位置与件 6 点 2 次等角写像変換 二乗平均残差 $=1.85 \mathrm{~m}$ 最大值 $=5.20 \mathrm{~m}$ Result of Block Adjustment A-16

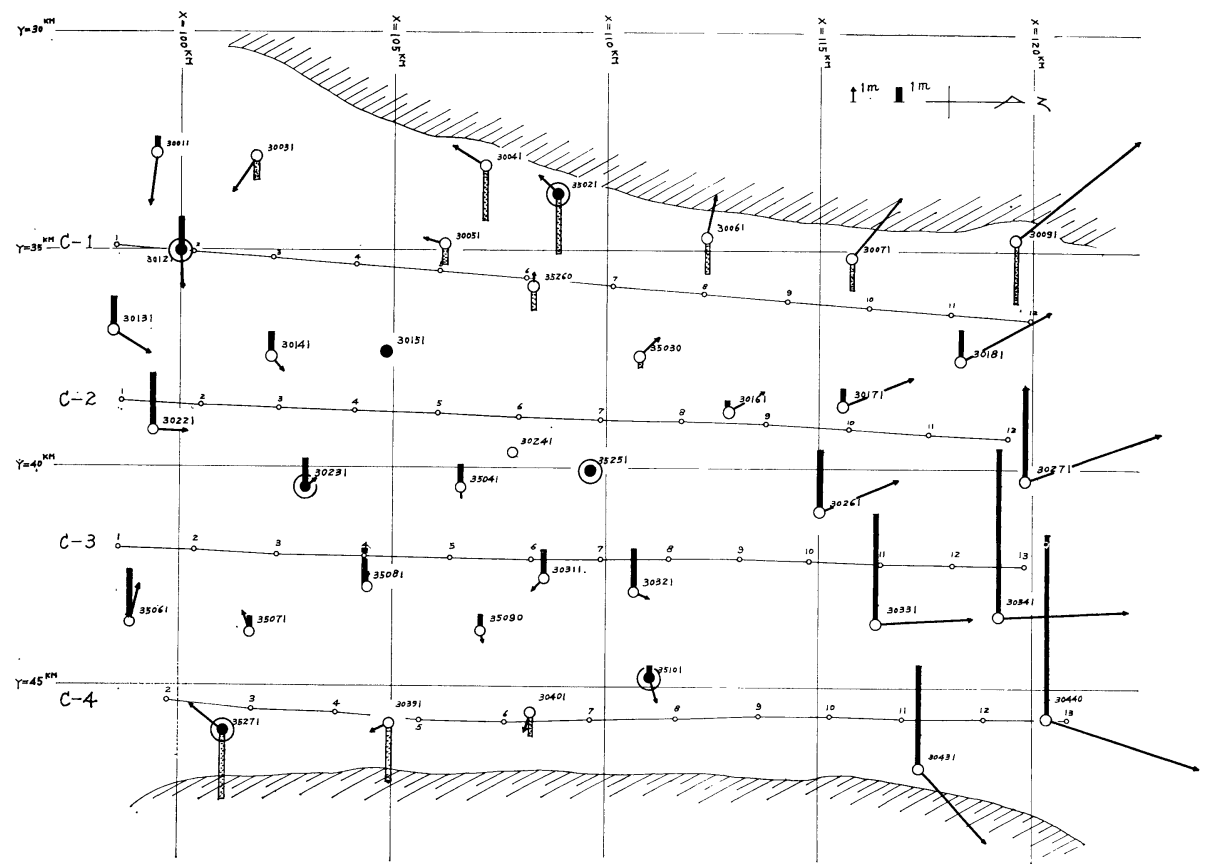

図20.〔A-17〕右半分オープン 位置与件 6 点 1 次等角写像変換 二乗平均残差 $=4.53 \mathrm{~m}$ 最大値 $=11.29 \mathrm{~m}$ Result of Block Adjustment A-17 


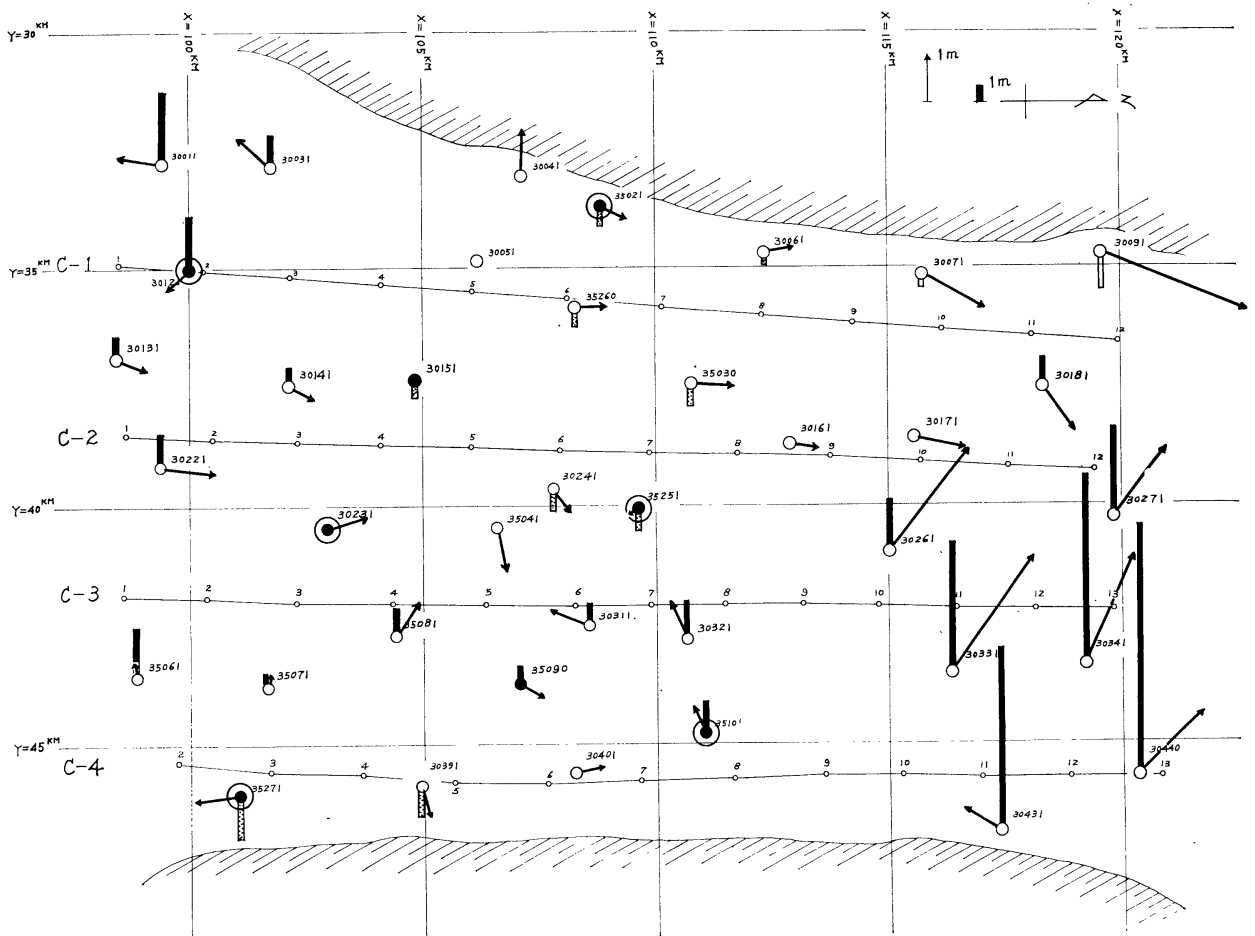

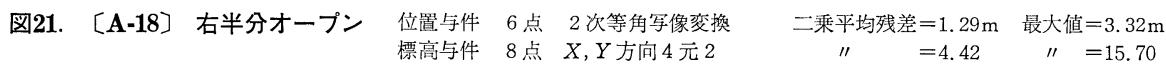
Result of Block Adjustment A-18

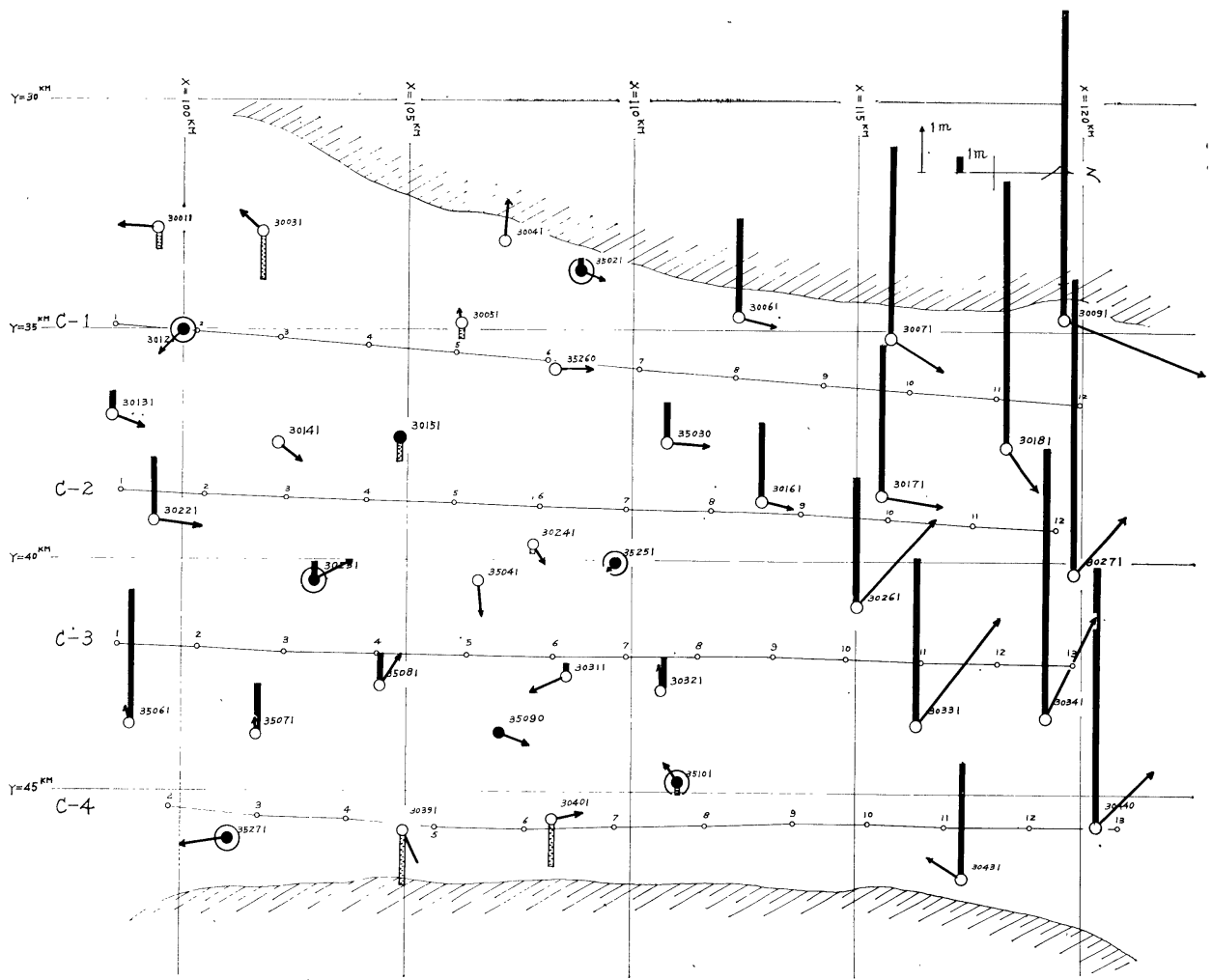

図22. [A-19] 右半分オープン 位置与件 6 点 2 次等角写像変換 二乗平均残差 $=1.29 \mathrm{~m}$ 最六値 $=3.32 \mathrm{~m}$ Result of Block Adjustment A-19 


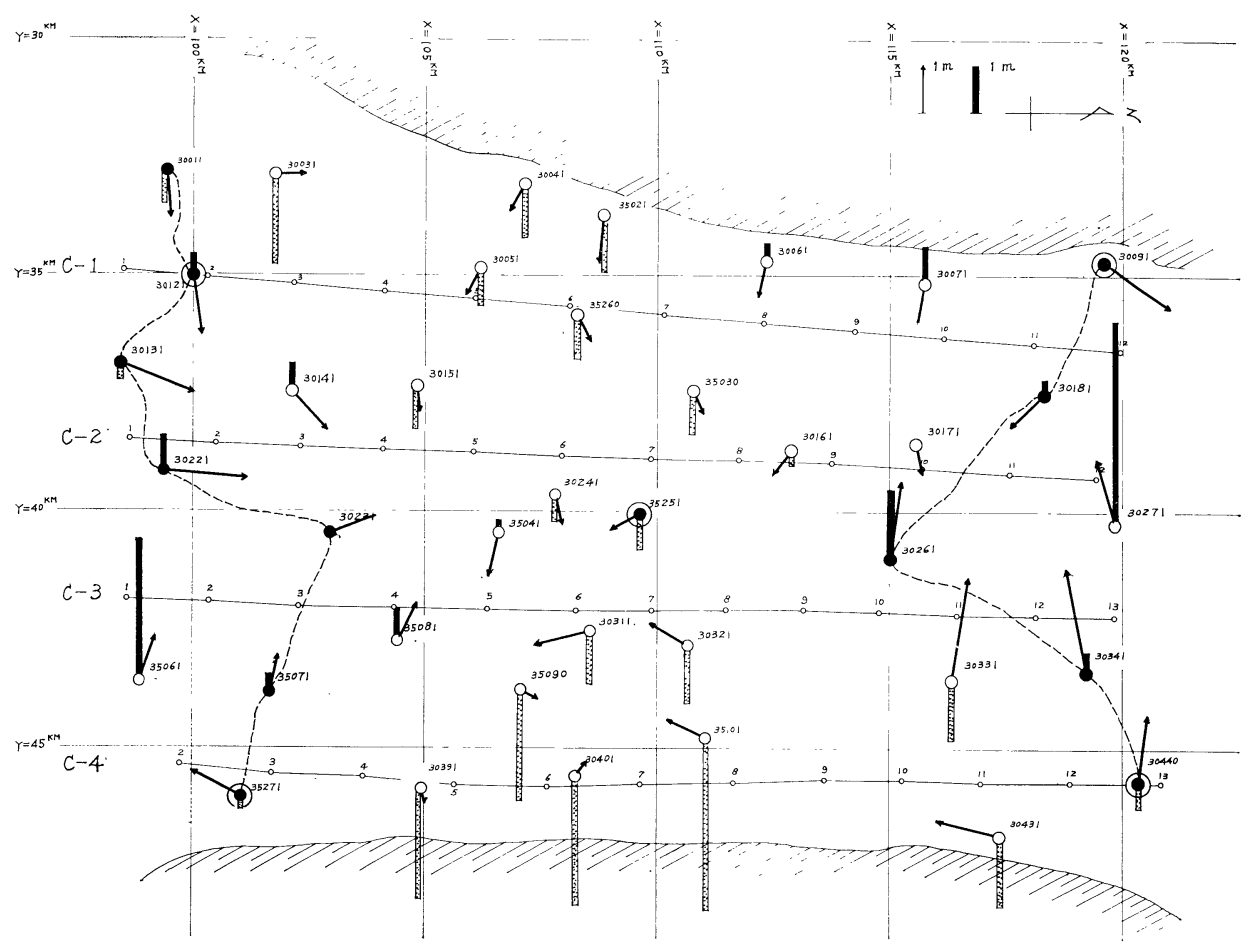

図23.【B-1〕位置与件 5 点 2 次等角写像変換 二乗平均残差 $=1.14 \mathrm{~m}$ 最大値 $=2.24 \mathrm{~m}$ 標高与件 13 点 $X$ 方向 5 元 2 次変挫
Result of Block Adjustment B-1

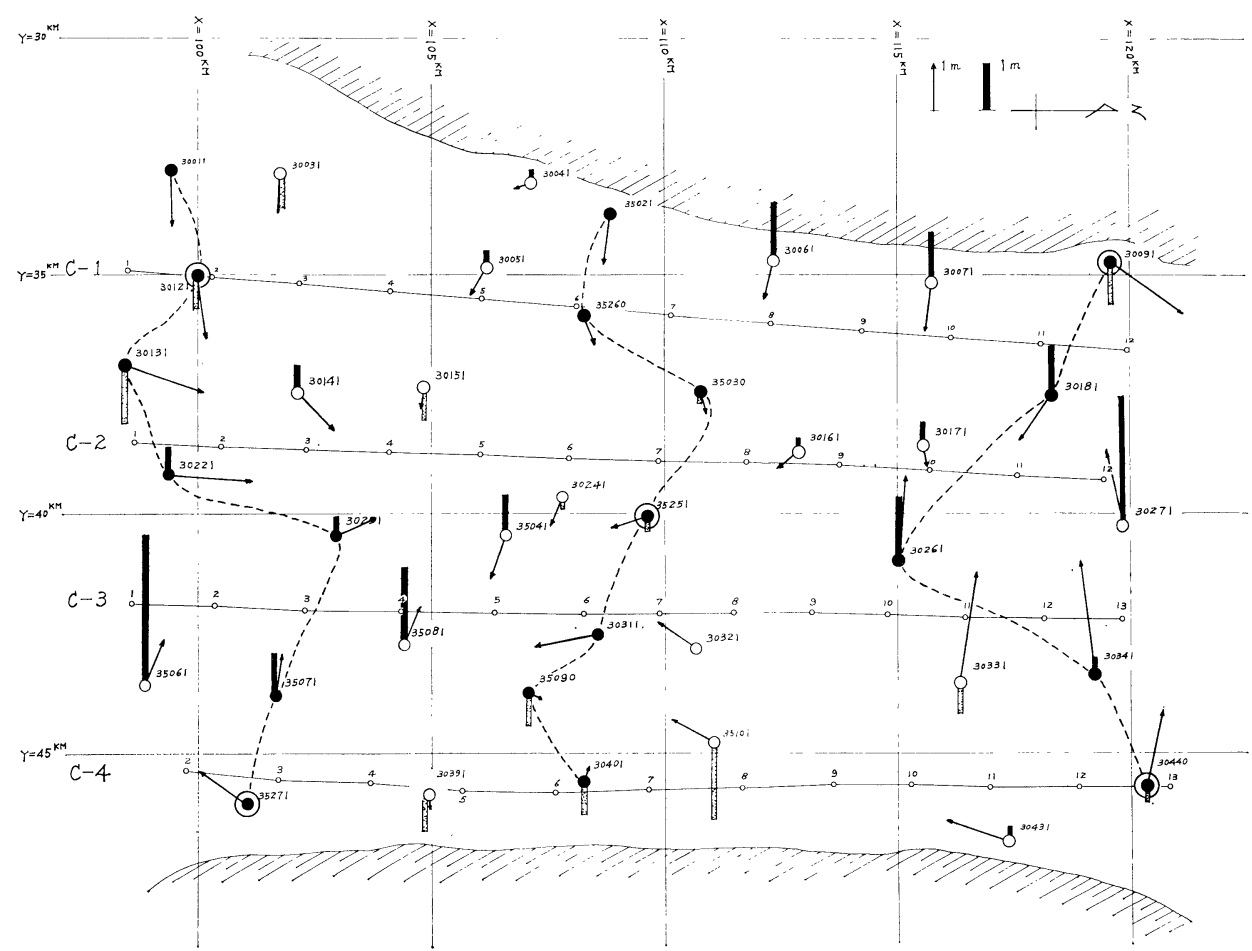

図24.〔B-2〕位置与件 5 点 2 次等角写像変換 標高与件 18 点 $X$ 方向 5 元 2 次変换 Result of Block Adjustment B-2 $\begin{aligned} \text { 二乗平均残差 } & =1.20 \mathrm{~m} \\ \prime \prime & \text { 最大值 }=2.43 \mathrm{~m} \\ & =1.00 \quad " \quad=3.20\end{aligned}$ 


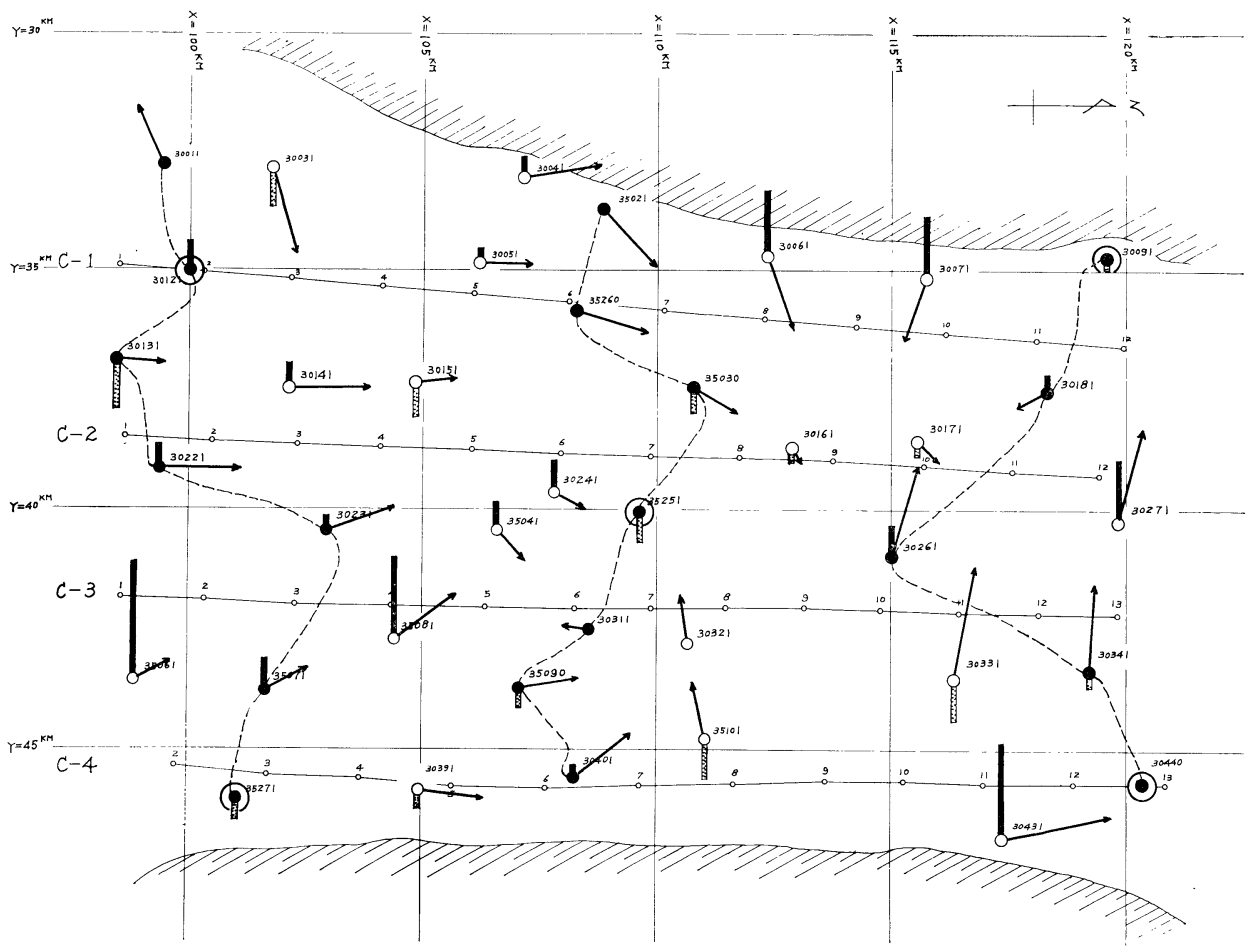

図25.〔B-4〕位置与件 5 点 4 次等角写像変換 二乗平均残差 $=1.34 \mathrm{~m}$ 最大値 $=2.48 \mathrm{~m}$ 標高与件 18 点 $X, Y$ 方们 6 元 2 次 Result of Block Adjustment B-4

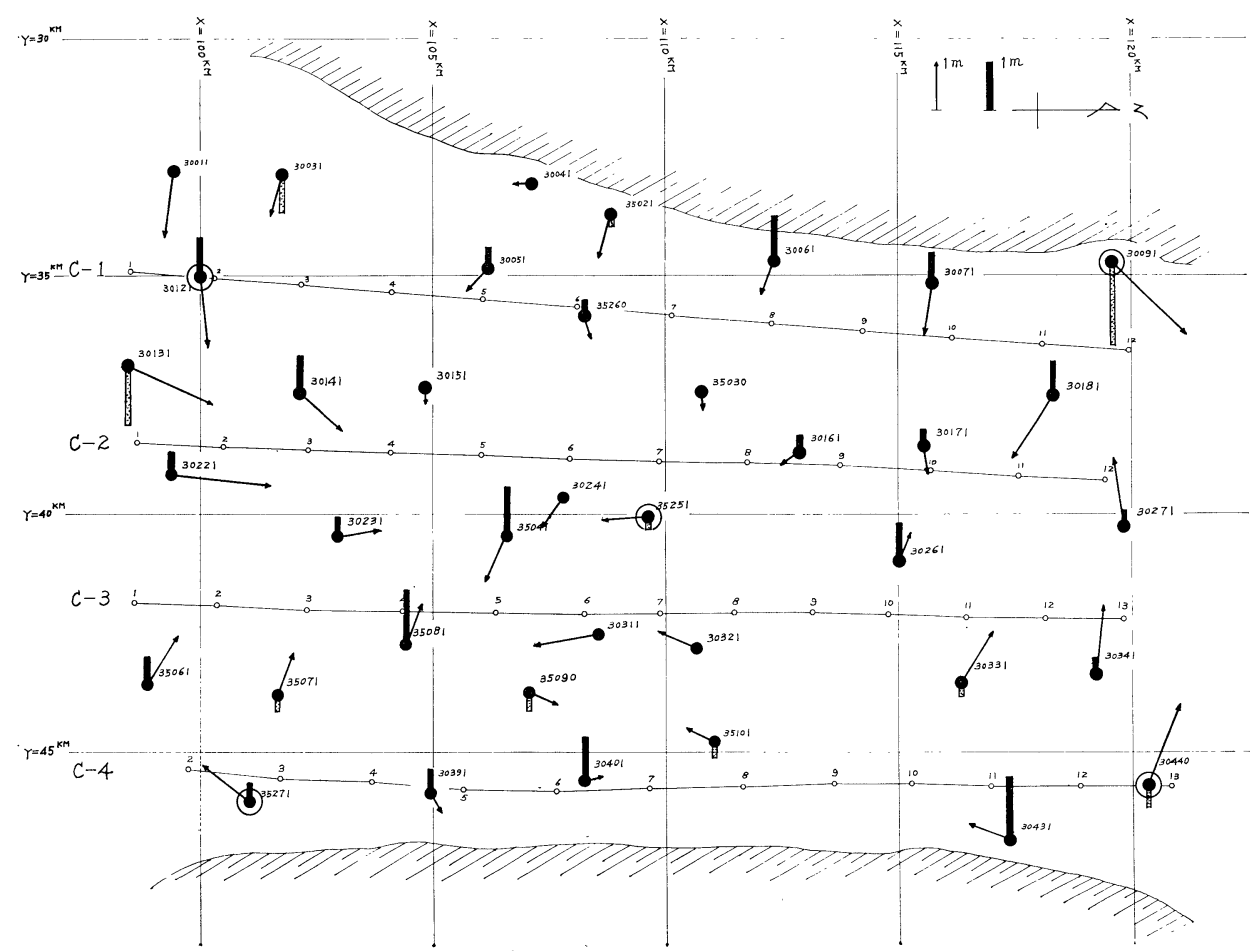

図26.【B-5〕位置与件 5 点 2 次等角写像変換 二乗平均残差 $=1.15 \mathrm{~m}$ 最大值 $=2.20 \mathrm{~m}$ Result of Block Adjustment B-5 